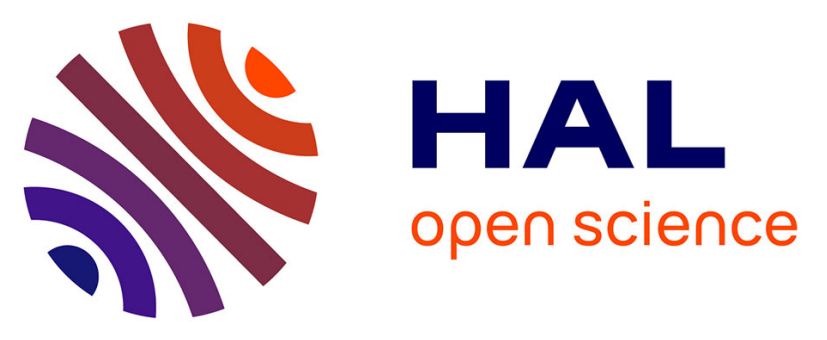

\title{
Single chamber Solid Oxide Fuel Cells selective electrodes: A real chance with brownmillerite-based nanocomposites
}

Andrea Bedon, Jean-Paul Viricelle, Mathilde Rieu, Simone Mascotto, Antonella Glisenti

\section{To cite this version:}

Andrea Bedon, Jean-Paul Viricelle, Mathilde Rieu, Simone Mascotto, Antonella Glisenti. Single chamber Solid Oxide Fuel Cells selective electrodes: A real chance with brownmilleritebased nanocomposites. International Journal of Hydrogen Energy, 2021, 46 (27), pp.14735-14747. 10.1016/j.ijhydene.2021.01.220 . emse-03164274

\section{HAL Id: emse-03164274 \\ https://hal-emse.ccsd.cnrs.fr/emse-03164274}

Submitted on 22 Mar 2021

HAL is a multi-disciplinary open access archive for the deposit and dissemination of scientific research documents, whether they are published or not. The documents may come from teaching and research institutions in France or abroad, or from public or private research centers.
L'archive ouverte pluridisciplinaire HAL, est destinée au dépôt et à la diffusion de documents scientifiques de niveau recherche, publiés ou non, émanant des établissements d'enseignement et de recherche français ou étrangers, des laboratoires publics ou privés. 


\section{Single Chamber Solid Oxide Fuel Cells selective}

\section{electrodes: a real chance with brownmillerite-based}

\section{nanocomposites}

Andrea Bedon ${ }^{a, b^{*}}$, Jean Paul Viricelle ${ }^{c}$, Mathilde Rieu $^{c}$, Simone Mascotto ${ }^{d}$, and Antonella Glisenti $^{b e^{*}}$

a Efesto Innovation s.r.l., via Trieste 19 - 35121 Padova, Italy

b Department of Chemical Sciences, University of Padova, via F. Marzolo 1 - 35131 Padova, Italy

c École Nationale Supérieure des Mines, SPIN-EMSE, CNRS:UMR5307, LGF, F-42023 SaintÉtienne - Université de Lyon, France

d Institut für Anorganische und Angewandte Chemie, Universität Hamburg, Martin-Luther-KingPlatz 6, 20146 Hamburg, Germany

e CNR-ICMATE, via F. Marzolo 1, 35131 Padova, Italy

* corresponding Authors - abedon@efestoinnovation.it; $\underline{\text { antonella.glisenti@unipd.it }}$

KEYWORDS. Single-Chamber Solid Oxide Fuel Cell, brownmillerites, iron oxide nanocomposites, selective electrodes 
ABSTRACT. In this contribution brownmillerite-based nanocomposite cathode for SingleChamber Solid Oxide Fuel Cells is developed. These cells can be very attractive especially for small and cheap devices because of the absence of seals. The efficiency of SC-SOFCs is strictly connected to the selectivity of anode and cathode, the bottleneck for this technology. The development of a cathode inert in fuel oxidation is particularly challenging. Our strategy is to start from a catalytically un-active support $\left(\mathrm{CFA}=\mathrm{Ca}_{2} \mathrm{FeAl}_{0.95} \mathrm{Mg}_{0.05} \mathrm{O}_{5}\right)$ and induce the formation of iron oxide based nanoparticles, expected to activate oxygen. Symmetric $\left(\mathrm{CFA}+\mathrm{FeO}_{\mathrm{x}} / \mathrm{CGO} / \mathrm{CFA}+\mathrm{FeO}_{\mathrm{x}}\right)$ and complete cells $\left(\mathrm{CFA}+\mathrm{FeO}_{\mathrm{x}} / \mathrm{CGO} / \mathrm{Ni}-\mathrm{CGO}\right)$ are studied in air and methane/oxygen 2:1 mixture. The Area Specific Resistance of $\mathrm{CFA}+\mathrm{FeO}_{\mathrm{x}}$ is less than $1 / 3$ that of CFA. The high selectivity allows to reach an efficiency of $25 \%$; power still needs to be increased but we demonstrated the possibility to develop selective low cost electrodes. The effect of air, methane/oxygen exposure and the heat treatments were carefully investigated.

\section{Introduction}

Solid Oxide Fuel Cell technology is in a period of great development and since now, has been reserved to stationary applications, due to their size and their thermomechanical fragility.

A particular type of SOFC has been proposed and studied: Single Chamber SOFC (SC-SOFC). A SC-SOFC [1,2] resolves most of the flaws of a traditional SOFC and in principle would have several advantages $[3,4]$, especially for small and cheap devices. In the SC-SOFCs both the electrodes are immersed in the same atmosphere. The obtainment of an effective sealing at high temperature is complicated, and tight connections between the cell and the other sealing elements can be the source of tensions leading to failures. For Single Chamber devices, cell design becomes more compact, and in general fabrication is easier. Moreover, specific applications can be devised; an example is the use of SC-SOFCs operating with exhaust gases in thermal engines[5]. In this 
application the cell might be embedded at the outlet of engine and could turn unburned hydrocarbons present in the exhaust gas into electricity allowing, for instance the energy supplying of electronic devices in vehicles; such application can also consider all cases in which hydrocarbons are burnt, as in stationary power plants

After start-up, SC-SOFCs can operate without external heating, because the direct oxidation of fuel by oxygen is exothermal and can sustain autonomously the cell, at expense of a fraction of efficiency. The main drawbacks are the low efficiency due to parasitic reactions, and the risk of explosion related to the presence of fuel and oxygen in the same mixture. For safety reasons, SCSOFCs are fed only with methane and rarely with hydrogen; methane at the anode is subjected to partial oxidation and the syngas produced is the real fuel [6].

In SC-SOFCs the selectivity of electrode materials for the respective electrochemical reaction is critical, and has been the main restrain to a large diffusion of these devices. No material turned out to have the selectivity required, and only a maximum $8 \%$ efficiency has been reached[4]. Instead, great advancements were accomplished in cell design, with indisputably good results in terms of cell power [7].

Coplanar cells are electrolyte plates in which both the electrodes are printed on the same side[8,9]. Flow-through cells (also named Mixed Reactant Cell) in which the gas mixture is forced through repeated porous layers of cathode, electrolyte and anode are another possibility.[10]

Riess [6,11-13], stressed the importance of the selectivity of the electrodes on SC-SOFCs performance. A SC-SOFC is operated in an anomalous way compared to other cells. A strong imbalance in fuel (methane)/oxygen ratio, which ranges between 1 and $2[14,15]$ and a high gas flow, allow a large part of the fuel to pass through the cell unreacted. 
The oxygen poor mixture is necessary to promote selective methane partial oxidation to syngas at the anode [6]. The cathode should not be able to catalyse methane oxidation, and hardly methane can be used directly for electrochemical oxidation. Syngas is the real fuel so feeding this mixture of methane and oxygen is a way to feed fuel only at the anode. Feeding directly with syngas would lead to loss of performances, because the cathode is able to electrocatalyse its oxidation. A fake but effective selectivity of the anode can be created with a fuel rich mixture, but the cathode must be selective by itself. A single chamber cell with an efficient cathode could operate with low flows and reach high fuel utilization efficiencies, up to $25 \%$ each cell and to $1-(3 / 4)^{\mathrm{n}}$ for a stack of $\mathrm{n}$ cells [6].

Electrochemical reactions require limited residence times, while chemical reactions, that should be suppressed in a SC-SOFC, take longer times; as a reference, $10 \mathrm{~ms}$ is a suitable time for electrocatalysis reactions while being low enough to avoid catalytic effect [12]. Thus, high flow is a mean to decrease residence times and to avoid the catalytic effect of the used materials, but that entails a very low fuel utilization; residence time is also influenced by materials porosity, cell geometry and gas flow. Anode activity is stressed by the mixed atmosphere (stability, deactivation due to the reduction/oxidation cycles) [16] [17,18].

Aim of the present work is to developed a perovskite/brownmillerite nanocomposite in which the perovskite is selected for catalytic selectivity toward oxygen reduction and the brownmillerite for ionic and electronic conductivity: this is expected to help obtaining a selective cathode for SCSOFC. 
Several materials, mainly perovskites, have been considered interesting to improve selectivity and stability of cathode: ferrites, cobaltates, manganates [19-28]: among these we focused on iron containing ones.

All materials used as SOFC cathodes are Mixed Ionic Electronic Conductive (MIEC) oxides or composites of MIEC materials [29]. Several perovskite based oxides show good oxygen ion mobility and conductivity [30-32] as well as electronic conductivity [33] but are characterized by high catalytic activity in oxidation. Because of this reason, among MIECs the choice has been restricted to a brownmillerite $\left(\mathrm{A}_{2} \mathrm{~B}_{2} \mathrm{O}_{5}\right)$ of the type $\mathrm{Ca}_{2} \mathrm{FeAlO}_{5}$ (CFA) [34]. In principle, CFAbased oxides are less reactive than perovskites toward oxidation and are characterized by a good chemical stability. The brownmillerite structure differs from the perovskite one for the presence of ordered oxygen vacancies in the (010) plane. Depending on the B cation and on the synthesis procedure, fully (Ibm2 and Pnma) or not fully (Icmm) ordered structures can be obtained. The presence of cations that prefer tetrahedral coordination (as $\mathrm{Al}$ ) contribute to increase the stability. The distribution of $\mathrm{Al}$ and $\mathrm{Fe}$ in $\mathrm{Ca}_{2} \mathrm{Fe} \mathrm{AlO}_{5}$ follows the "homogeneous layer principle":[35] $\mathrm{Al}$ and $\mathrm{Fe}$ tend to form homogeneous octahedral layers or tetrahedral chains rather than mixed layers or chains of two elements along the $b$ axis. To improve conductivity, a small amount of magnesium was inserted, so the actual formula of CFA is $\mathrm{Ca}_{2} \mathrm{FeAl}_{0.95} \mathrm{Mg}_{0.05} \mathrm{O}_{5}$ [36]. Also Co-doping was considered in literature for improving conductivity [37-39] in our work we decided to avoid the use of Critical Raw Materials and $\mathrm{Mg}$ was preferred. The substitution of $\mathrm{Al}(\mathrm{III})$ with $\mathrm{Mg}$ (II) should help increasing $\mathrm{Fe}(\mathrm{IV})$ amount for charge compensation. $\mathrm{Mg}$ also affects the structure having a high octahedral site preference (higher than Fe(III)) and enhances the number of iron cations in tetrahedral environment; its solubility in CFA is low $(<0.1)$ [36]. After its synthesis by citric acid route, CFA has been characterized by means of XRD, TPR, SEM, XPS, EDX and $\mathrm{N}_{2}$ adsorption 
isotherms; its catalytic activity towards methane oxidation has been measured; once verified the low activity toward methane oxidation, CFA was selected as the MIEC support for the catalytically active phase.

Following literature, that underline the capability of iron containing oxides to dissociatively chemisorb oxygen [40-43] and our previous experience, the supporting CFA powder has been impregnated with iron and thermally treated with the aim of inducing the formation of a catalytically active iron based active phase enclosed in a brownmillerite. We refer to this second material as $\mathrm{CFA}+\mathrm{FeO}_{\mathrm{x}}$. Catalysis and electrocatalysis are diffuse applications of these nanocomposition techniques. [44-46] To the best of our knowledge brownmillerite-based nanocomposites are not so diffused and some few example concerns composites of the type perovskite/brownmillerites.[47-48]

Symmetrical cells with Cerium Gadolinium Oxide (CGO) electrolyte have been prepared using both CFA and CFA $+\mathrm{FeO}_{\mathrm{x}}$ for electrochemical impedance spectroscopy (EIS) tests. The electrode firing temperature has been optimized; complete cells with a Ni/CGO anode have been fabricated and their polarization curves have been measured. The same treatments necessary to assure electrode/electrolyte adhesion have been carried out to the $\mathrm{CFA}+\mathrm{FeO}_{\mathrm{x}}$ powders to better investigate the evolution of nanocomposite during the device optimization.

\section{Synthesis and characterization}

CFA has been synthesized with a solid combustion synthesis. Precursors $\mathrm{CaCO}_{3}, \mathrm{Fe}, \mathrm{Al}\left(\mathrm{NO}_{3}\right)_{3}$ and $\mathrm{Mg}(\mathrm{OH})_{2}$ were dissolved in water with the help of $\mathrm{HNO}_{3}$ when needed. Citric acid in amount 
1.9 times the cations in solution was then added. The solution was neutralized adding drop-bydrop $\mathrm{NH}_{4} \mathrm{OH}$; water was eliminated by mildly heating on hot plate, gel formation happens at the end of this step. Increasing of hot-plate heating over $250^{\circ} \mathrm{C}$ triggers gel self-combustion. The obtained powder was grinded and calcined at $1050^{\circ} \mathrm{C}$ for $6 \mathrm{~h}$.

Iron oxide was deposited on CFA via a wet impregnation procedure in the amount of $10 \%$ mol.[49,50]. An aqueous solution of Fe(II) was prepared, and CFA was added to it. The suspension was covered and kept under stirring for one day. Mild heating on a hot plate was employed to evaporate water. The obtained powder was finally treated at $550^{\circ} \mathrm{C}$ for 6 hours.

Cells for EIS and polarization measurements are electrolyte supported and prepared by screen printing the material to be tested on both sides of a CGO pellet (diameter $20 \mathrm{~mm}$, thickness 1.4 $\mathrm{mm}$ ). The electrolyte was prepared by pressing the CGO powder (GDC10-TC, Fuel Cell Materials) and treating the so-obtained pellet at $1350^{\circ} \mathrm{C}$ for two hours. An ink was prepared by mixing the electrode (CFA or NiO) powder with a fraction of CGO powder, and adding binder V400 (ESL, commercial) and solvent T404 (ESL, commercial) to adjust viscosity. The ink deposition is carried out by means of a serigraphy machine. The layer is then dried in an oven at $100^{\circ} \mathrm{C}$ for 15 minutes. For symmetrical cells two layers on each side of the CGO pellets were printed; for complete cells cathode was printed with two CFA layers and anode with four NiO layers. Anodes were treated at $1200^{\circ} \mathrm{C}$ and cathodes were treated at 1000,1050 , and $1100^{\circ} \mathrm{C}$, to evaluate the temperature better ensuring a good electrical contact between the electrolyte and the electrodes. Treatments at temperatures lower than $1000^{\circ} \mathrm{C}$ have been found not to be sufficient to ensure enough mechanical stability to the electrodic layer. Finally, a gold grid is printed from a gold ink (8880-H, ESL, commercial) on both the electrodes, and the cell is treated a last time at $850^{\circ} \mathrm{C}$ for two hours. 
In order to evaluate the performances of the materials for SOFC operation, EIS tests were performed on the following symmetrical cells: two CFA/CGO/CFA cells and two $\mathrm{CFA}+\mathrm{FeO}_{\mathrm{x}} / \mathrm{CGO} / \mathrm{CFA}+\mathrm{FeO}_{\mathrm{x}}$ cells, each cell treated at a different temperature $\left(1000^{\circ} \mathrm{C}\right.$ to $1100^{\circ} \mathrm{C}$ ). Impedances of the cell were measured under air (normal operating condition for a double cell SOFC cathode), under a $20 \% \mathrm{CH}_{4} 10 \% \mathrm{O}_{2}$ atmosphere and then a second time under air. Data were collected with Solartron 1286 Electrochemical Interface and Solartron 1255 Frequency Response Analyzer devices. Prior to test, complete cells require anode activation, consisting in a reduction of $\mathrm{NiO}$ to $\mathrm{Ni}$, carried out with a $5 \mathrm{~min}$. treatment under $\mathrm{CH}_{4} 10 \%$ in $\mathrm{N}_{2}$ at $600^{\circ} \mathrm{C}$, then cell measurements were carried out under a $20 \% \mathrm{CH}_{4} 10 \% \mathrm{O}_{2}$ atmosphere. For the polarization curves of complete SC-SOFC, a Keithley 2400 SourceMeter was used. Selectivity tests of the cathodes were performed by sealing two alumina tubes at both sides of a complete cell with a commercial cement (Aremco Ceramabond 571). Tests were carried out on following cells: Ni-

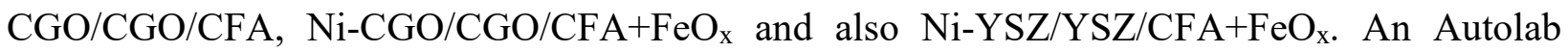
PGSTAT204 was used to keep the cell working during the test, voltage was set at $0.4 \mathrm{~V}$ to obtain the maximum power. A thermocouple at each side measured the cell temperature. An ESS Evolution quadrupole was used to measure composition of the cathode exhaust; the instrument was calibrated with a $\mathrm{CO}_{2}$ standard to obtain quantitative data. Each cathode was flushed with 140 sccm of a $20 \% \mathrm{CH}_{4}$ and $10 \% \mathrm{O}_{2}$ gas mixture.

X-ray photoelectron spectroscopy (XPS) measurements were carried out with a Perkin Elmer $\Phi$ 5600ci Multi Technique System. The spectrometer was calibrated by assuming the binding energy (BE) of the $\mathrm{Au} 4 \mathrm{f}_{7 / 2}$ line to be $84.0 \mathrm{eV}$ with respect to the Fermi level. Both extended spectra (survey - $187.85 \mathrm{eV}$ pass energy, $0.5 \mathrm{eV} \cdot \mathrm{step}^{-1}, 0.05 \mathrm{~s} \cdot \mathrm{step}^{-1}$ ) and detailed spectra (for $\mathrm{Ca} 2 \mathrm{p}, \mathrm{Fe}$ 2p, Al 2p, Mg 1s, O 1s and C 1s $-23.50 \mathrm{eV}$ pass energy, $\left.0.1 \mathrm{eV} \cdot \mathrm{step}^{-1}, 0.1 \mathrm{~s} \cdot \mathrm{step}^{-1}\right)$ were collected 
with a standard $\mathrm{Al} \mathrm{K \alpha}$ source working at $250 \mathrm{~W}$. The standard deviation in the BE values of the XPS line is $0.10 \mathrm{eV}$. The atomic percentage, after a Shirley-type background subtraction [51], was evaluated by using the PHI sensitivity factors [52]. The peak positions were corrected for the charging effects by considering the $\mathrm{C} 1 \mathrm{~s}$ peak at $285.0 \mathrm{eV}$ and evaluating the BE differences [53].

X-ray diffraction (XRD) analyses were performed with a Bruker D8 Advance diffractometer with Bragg-Brentano geometry using a $\mathrm{Cu} K \alpha$ radiation $(40 \mathrm{kV}, 40 \mathrm{~mA}, \lambda=0.154 \mathrm{~nm})$. The data were collected at $0.03^{\circ}$ at a counting time of $10 \mathrm{~s} \mathrm{step}^{-1}$ in the $(2 \theta)$ range from $10^{\circ}$ to $60^{\circ}$. The crystalline phases were identified by the search-match method using the JCPDS database.

Temperature Programmed Reduction (TPR) was performed with an Autochem II 2920 Micromeritics, equipped with a Thermal Conductivity Detector (TCD). The TPR measurements were carried out in a quartz reactor by using $50 \mathrm{mg}$ of sample and heating from $\mathrm{RT}$ to $900^{\circ} \mathrm{C}$ at $10^{\circ} \mathrm{C} \mathrm{m^{-1 }}$ under a constant flow of $\mathrm{H}_{2} 5 \%$ in $\operatorname{Ar}\left(50 \mathrm{ml} \cdot \mathrm{min}^{-1}\right)$. TPR samples were previously outgassed with $\mathrm{He}\left(50 \mathrm{ml} \cdot \mathrm{min}^{-1}\right)$ at room temperature.

Nitrogen adsorption isotherms were measured at 77K with a Micromeritics ASAP 2020 plus instrument. Superficial area by BET model has been calculated from adsorption curves. DFT calculations were carried out with built-in software of the instrument.

Field emission-scanning electron microscopy and EDX measures were carried on a Zeiss SUPRA 40VP. Morphological and EDX analysis were carried out setting the acceleration voltages at 20 $\mathrm{kV}$. The powder was positioned on the sample holder by means of a high vacuum conductive Cbased adhesive and analysed without any further treatment. 
Transmission electron microscopy (TEM) and selected area electron diffraction (SAED) measurements were carried out on a JEOL JEM 1011. The sample was grinded into a fine powder, which was suspended in toluene by sonication and dropped on a carbon coated 400 mesh TEM grid. The excess of solvent was removed with a filter paper and by drying the grid under air.

The catalytic activity was measured placing $100 \mathrm{mg}$ of CFA in the middle of a vertical quartz tube, with a $7 \% \mathrm{O}_{2}, 14 \% \mathrm{CH}_{4}$ gas mixture flowing upside, with a $100 \mathrm{sccm}$ flow. The exhaust composition was measured with a GC.

\section{Results and discussion}

\subsection{XRD}

CFA pattern (Figure 1Sa -Supporting Information) matches with a brownmillerite phase $\mathrm{Ca}_{2} \mathrm{FeAlO}_{5}$ : the magnesium concentration is only minimal and insufficient to produce significant deviations from parent $\mathrm{Ca}_{2} \mathrm{FeAlO}_{5}$ structure but probably un-favours crystalline order. Brownmillerite's crystal structure is similar to the perovskite's one, from which it can be obtained with the ordered removal of one oxygen atom every six [54]. With this transformation, each layer every two of the perovskite becomes a layer of tetrahedral [55], and symmetry changes from cubic to orthorhombic. A small krotite $\left(\mathrm{CaAl}_{2} \mathrm{O}_{4}\right)$ impurity is also present.

After the impregnation with Fe-based solution the phase composition is deeply changed (Figure 1Sb): three new phases appeared, all of them containing calcium, oxygen and one other element between Fe and Al. Their formation suggests the decomposition of the brownmillerite, with Fe and $\mathrm{Al}$ cations separating in two different phases. One possible phase could be $\mathrm{Ca}_{2} \mathrm{Fe}_{2} \mathrm{O}_{5}$, which is very similar to the original $\mathrm{Ca}_{2} \mathrm{FeAlO}_{5}$ and has the same brownmillerite structure. In fact, 
srebrodolskite is the name of a mineral with composition $\mathrm{Ca}_{2} \mathrm{Fe}_{2} \mathrm{O}_{5}$ and the brownmillerite crystalline structure. The mayenite $\left(\mathrm{Ca}_{12} \mathrm{Al}_{14} \mathrm{O}_{33}\right)$, despite its formula similar to the brownmillerite (that would be $\mathrm{Ca}_{14} \mathrm{Al}_{14} \mathrm{O}_{35}$ ) has a very different crystalline structure.

A treatment at $1050^{\circ} \mathrm{C}$, which replicates the firing of the electrodes to make them adhere to the electrolyte, restores the original $\mathrm{Ca}_{2} \mathrm{FeAlO}_{5}$ phase (Figure $1 \mathrm{Sc}$ ). This means that when preparing a cell with the iron impregnated powder, the electrode is deposited as a mixture of $\mathrm{Ca}_{12} \mathrm{Al}_{14} \mathrm{O}_{33}$, $\mathrm{Ca}_{2} \mathrm{Fe}_{2} \mathrm{O}_{5}, \mathrm{CaCO}_{3}$, and then reverts to the pristine brownmillerite during the firing. Traces of the spinel $\mathrm{CaAl}_{2} \mathrm{O}_{2}$ are again observed, and there still is some trace of calcite, close to the detection limit. It is possible that CFA decomposes in $\mathrm{Ca}_{2} \mathrm{Fe}_{2} \mathrm{O}_{5}$ and $\mathrm{CaAl}_{2} \mathrm{O}_{4}$. In general, signal/noise ratio is worse than as-synthesized brownmillerite.

\section{2. $\mathrm{N}_{2}$ isotherms and superficial area}

The specific surface area of CFA is low, $1.7 \mathrm{~m}^{2} / \mathrm{g}$; the CFA isotherm is type II (Figure S2). CFA $+\mathrm{FeO}_{\mathrm{x}}$ treated at $1050^{\circ} \mathrm{C}$ has a higher specific surface area, $17.1 \mathrm{~m}^{2} / \mathrm{g}$, and the isotherm is type $\mathrm{V}$ (Figure S2). This is consistent with the phase modifications observed by means of XRD. Other than the different curve shape, in $\mathrm{CFA}+\mathrm{FeO}_{\mathrm{x}}$ also a hysteresis loop appeared. Loops in gas physisorption measurements form due to capillary condensation of the adsorbate and identify the presence of mesoporosity. This loop shape, of type H3, is associated to disordered pores. From adsorption curves it is possible to perform DFT calculations to analyse the $\mathrm{CFA}+\mathrm{FeO}_{\mathrm{x}}$ treated at $1050^{\circ} \mathrm{C}$ pore distribution. Such procedure reveals a porosity distribution with average pore size of $22 \mathrm{~nm}$. 


\subsection{SEM and TEM}

CFA powder, Figure 1, is in form of conglomerated particles of size around $200 \mathrm{~nm}$; the shape of the particle appears smooth and irregular, no particular feature is observed.

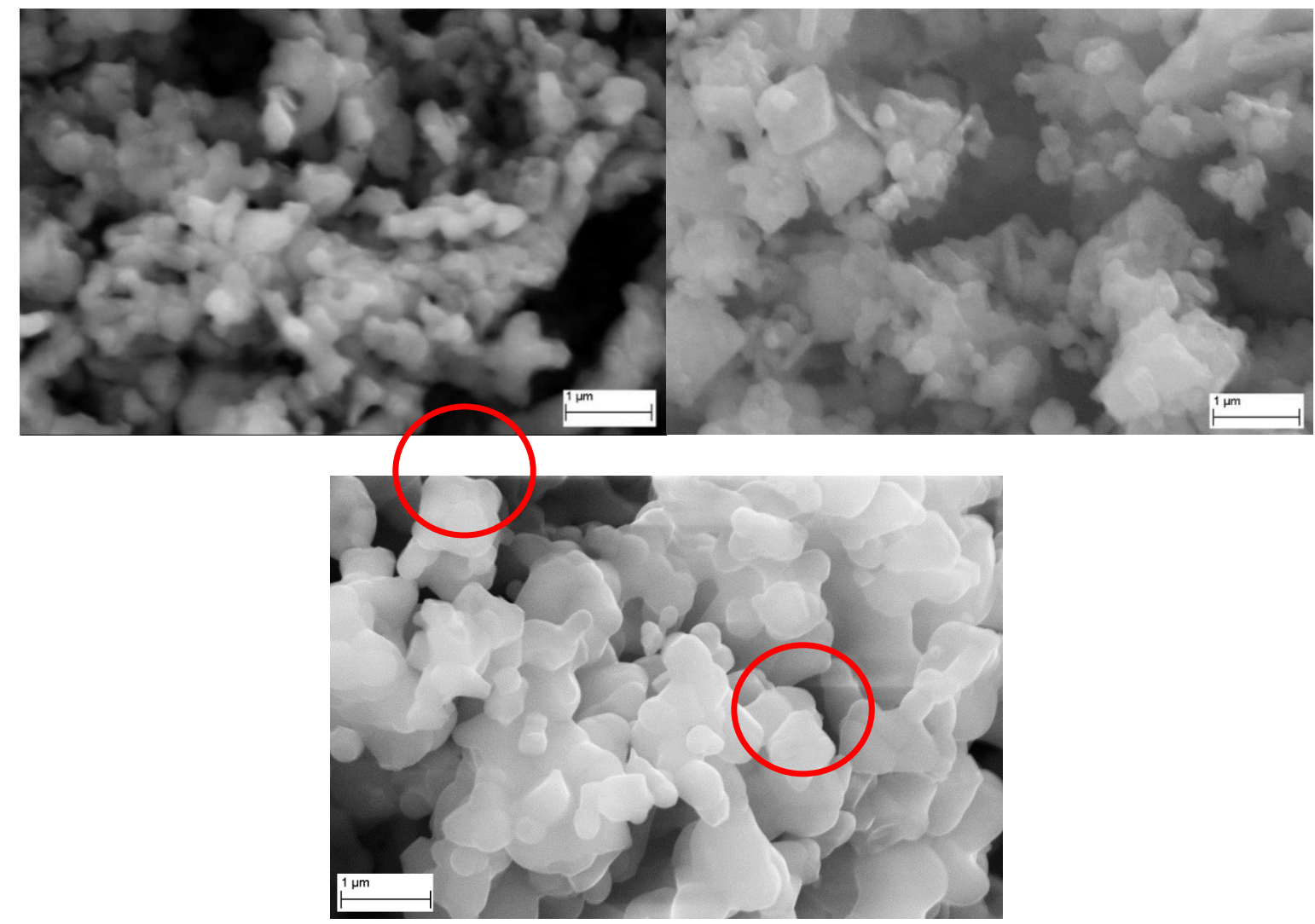

Figure 1. SEM images of CFA (above, left), CFA $+\mathrm{FeO}_{\mathrm{x}}$ (above, right) and $\mathrm{CFA}+\mathrm{FeO}_{\mathrm{x}}$ (below) treated at $1050^{\circ} \mathrm{C}$. Red circles highlight octahedron-like particles.

In the image of $\mathrm{CFA}+\mathrm{FeO}_{\mathrm{x}}$ powder, some crystals with an octahedral shape and $1 \mu \mathrm{m}$ size are mixed with smaller and less defined particles. The morphology change is a result of the formation of a new crystal phase (see XRD) and the presence of a highly porous structure. After the $1050^{\circ} \mathrm{C}$ thermal treatment the original dense structure is restored. Contrary to CFA, after the thermal treatment $\mathrm{CFA}+\mathrm{FeO}_{\mathrm{x}}$ is an agglomerate of very different size of particles, from around $200 \mathrm{~nm}$ 
to more than $1 \mu \mathrm{m}$. This different size distribution can be a consequence of the formation of a composite structure with different chemical compositions. During the treatment the atoms moved along the existing structures and recombined maintaining the shape of the bigger particles. Thus, the final structure (evidenced in Figure 2) has a shape reminiscent of an octahedron.
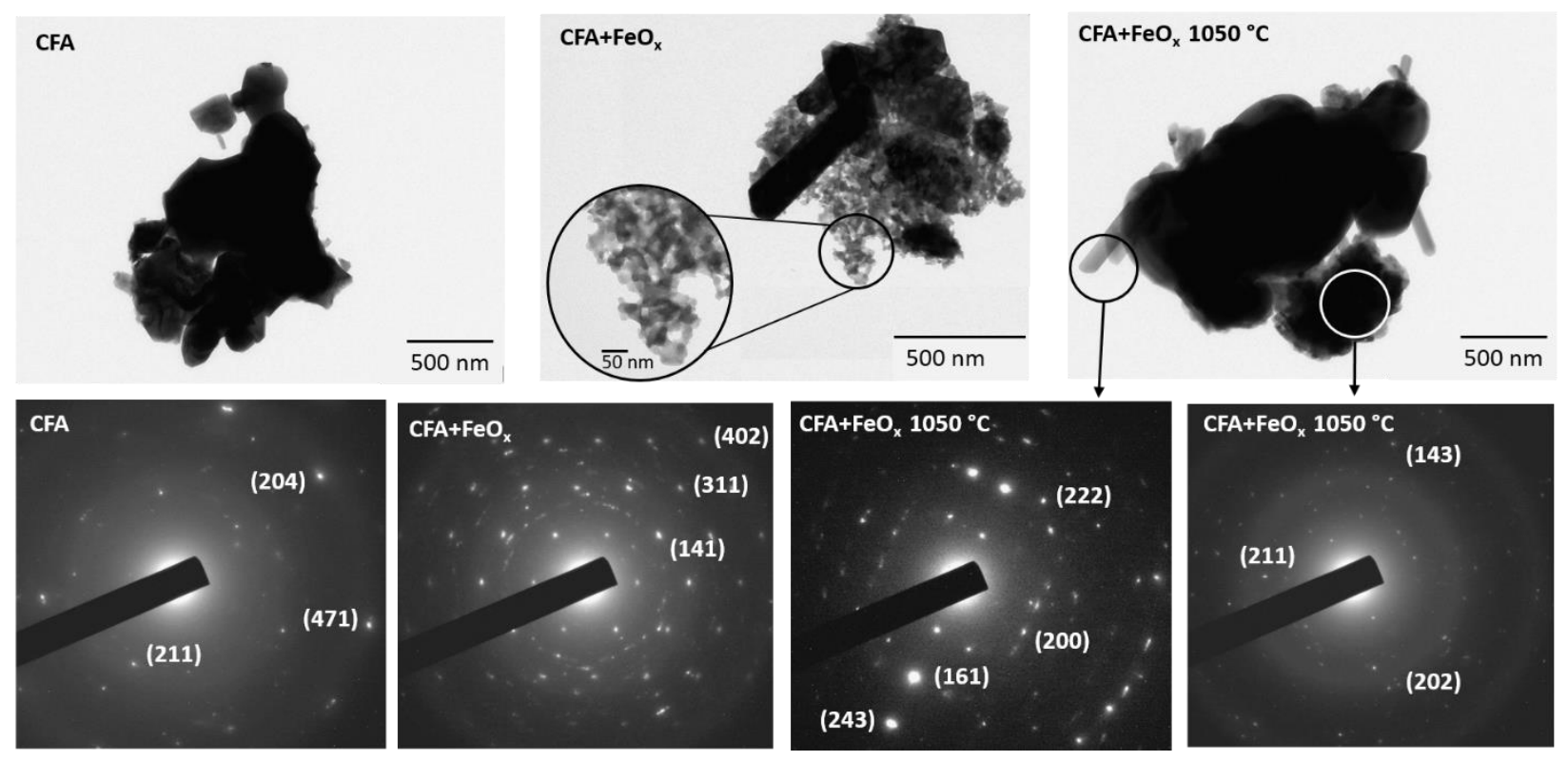

Figure 2: TEM micrographs and corresponding SAED patterns of $\mathrm{CFA}, \mathrm{CFA}+\mathrm{FeO}_{\mathrm{x}}$, and $\mathrm{CFA}+\mathrm{FeO}_{\mathrm{x}} 1050$.

Detailed information on the local structure of the different materials were obtained by TEM and SAED analyses (Figure 2). CFA is characterized by cubic-like grains agglomerated dense structures typical of sintered systems. In $\mathrm{CFA}+\mathrm{FeO}_{\mathrm{x}}$ the material decomposition is evident. Here a highly mesoporous structure with pore size of approx. $20 \mathrm{~nm}$ is evidenced, in very good agreement with the nitrogen physisorption analysis. Also, anisotropic crystalline particles appear, which significantly differ from those in CFA. After the firing step at $1050^{\circ} \mathrm{C}$ the material sintered structured is restored. Along with the cubic-like particles, the elongated structures observed in $\mathrm{CFA}+\mathrm{FeO}_{\mathrm{x}}$ are still present. To get precise information on the chemical nature of the observed 
materials, electron diffraction studies were performed. In case of CFA, due to the large thickness of the agglomerates and the overlap of crystallites with different orientation, SAED patterns were not easy to be assigned. However, we successfully identified the presence of crystalline planes belonging to the $\mathrm{Ca}_{2} \mathrm{FeAlO}_{5}$ structure (01-070-1499). The nanostructured nature of $\mathrm{CFA}+\mathrm{FeO}_{\mathrm{x}}$ provided more insightful results. Among other phases, the presence of $\mathrm{Ca}_{5} \mathrm{Fe}_{2} \mathrm{O}_{5}(00-030-0226)$ reflections was demonstrated in good agreement with the XRD results. In $\mathrm{CFA}+\mathrm{FeO}_{\mathrm{x}}$ after sintering, the two crystalline structures clearly indicate the presence of two different crystal habits confirming the presence of a nanocomposite material. From the cubic-like particles we found evidences of $\mathrm{Ca}_{2} \mathrm{FeAlO}_{5}$ phase, confirming the XRD results. The anisotropic crystals present very clearly the $\mathrm{Ca}_{5} \mathrm{Fe}_{2} \mathrm{O}_{5}$ structure. The high intensity of the (161) reflection agrees very well with the anisotropic form of the crystal. Evidently, this brownmillerite phase formed after the Fe-solution impregnation step is maintained after firing. The missing information in XRD about the presence of this phase can be justified by the strong crystallographic overlap with the similar $\mathrm{Ca}_{2} \mathrm{FeAlO}_{5}$ brownmillerite structure.

\subsection{XPS and EDX}

Quantitative analysis of samples composition is shown in Table 1. In general, XPS suggests an excess of oxygen, consistent with surface hydroxylation. As typically observed in perovskite structures, XPS reveals a superficial segregation of the A-site cation. Regarding the B cations there is a relative abundance of $\mathrm{Al}$ compared to Fe instead of the nominal 1:1 ratio. Traces of $\mathrm{Mg}$ have been detected. The deposition of iron oxide, unexpectedly, favours the surface segregation of $\mathrm{Al}$ and this situation is not significantly affected by the following treatment at $1050{ }^{\circ} \mathrm{C}$. The amounts of cations determined by EDX are more in accordance with nominal compositions indicating that the segregation is limited to few surface monolayers. 


\begin{tabular}{|c|c|c|c|c|c|c|c|c|}
\hline & \multicolumn{2}{|c|}{ Nominal } & \multicolumn{3}{|l|}{ XPS } & \multicolumn{3}{|l|}{ EDX } \\
\hline & CFA & CFA+FeO & CFA & $\mathrm{CFA}+\mathrm{FeO}_{\mathrm{x}}$ & $\begin{array}{l}\mathrm{CFA}+\mathrm{FeO} \mathrm{x}_{\mathrm{x}} \\
1050^{\circ} \mathrm{C}\end{array}$ & CFA & $\mathrm{CFA}+\mathrm{FeO}_{\mathrm{x}}$ & $\begin{array}{l}\mathrm{CFA}+\mathrm{FeO}{ }_{x} \\
1050^{\circ} \mathrm{C}\end{array}$ \\
\hline $\mathrm{Ca}$ & \begin{tabular}{|l|}
22.2 \\
$(50.0)$ \\
\end{tabular} & \begin{tabular}{|l|}
22.0 \\
$(48.8)$ \\
\end{tabular} & \begin{tabular}{|l|}
18.0 \\
$(66.4)$ \\
\end{tabular} & \begin{tabular}{|l|}
15.9 \\
$(56.6)$ \\
\end{tabular} & \begin{tabular}{|l|}
17.4 \\
$(61.3)$ \\
\end{tabular} & $(49.1)$ & $(51.2)$ & $(47.8)$ \\
\hline $\mathrm{Fe}$ & $\begin{array}{l}11.1 \\
(25.0) \\
\end{array}$ & $\begin{array}{l}12.1 \\
(26.8) \\
\end{array}$ & \begin{tabular}{|l|}
2.9 \\
$(10.7)$ \\
\end{tabular} & \begin{tabular}{|l|}
3.1 \\
$(11.0)$ \\
\end{tabular} & \begin{tabular}{|l|}
3.2 \\
$(11.3)$ \\
\end{tabular} & $(22.3)$ & $(24.6)$ & (24.6) \\
\hline Al & \begin{tabular}{|l|}
10.6 \\
$(23.7)$ \\
\end{tabular} & \begin{tabular}{|l|l}
10.4 \\
$(23.2)$ \\
\end{tabular} & \begin{tabular}{|l|}
5.0 \\
$(18.5)$ \\
\end{tabular} & \begin{tabular}{|l|}
8.0 \\
$(28.5)$ \\
\end{tabular} & \begin{tabular}{|l|}
6.9 \\
$(24.2)$ \\
\end{tabular} & $(27.0)$ & $(24.2)$ & $(26.8)$ \\
\hline $\mathrm{Mg}$ & \begin{tabular}{|l|}
0.6 \\
$(1.3)$ \\
\end{tabular} & \begin{tabular}{|l|}
0.6 \\
$(1.2)$ \\
\end{tabular} & \begin{tabular}{|l|}
1.2 \\
$(4.4)$ \\
\end{tabular} & \begin{tabular}{|l|}
1.1 \\
$(3.9)$ \\
\end{tabular} & \begin{tabular}{|l|}
0.9 \\
$(3.2)$ \\
\end{tabular} & $(1.6)$ & & $(0.81)$ \\
\hline 0 & 55.6 & 55.0 & 72.9 & 71.9 & 71.6 & & & \\
\hline $\mathrm{Fe} / \mathrm{Al}$ & 1.06 & 1.16 & 0.58 & 0.39 & 0.47 & 0.83 & 1.02 & 0.92 \\
\hline$(\mathrm{Fe}+\mathrm{Al}) / \mathrm{Ca}$ & 0.97 & 1.02 & 0.52 & 0.70 & 0.58 & 1.00 & 0.95 & 1.08 \\
\hline
\end{tabular}

Table 1. Summary of quantitative analysis by means of XPS and EDX on powders. Abundances are indicated as atomic \% relative concentrations. Numbers in brackets refer to calculation considering only cations.

\subsection{TPR}

The TPR curves are shown in Erreur ! Source du renvoi introuvable.3, and the area of the peaks are summarized in Erreur ! Source du renvoi introuvable.. TPR profile of CFA reveals only two very small peaks at $450^{\circ} \mathrm{C}$ and $600^{\circ} \mathrm{C}$. The only species that can be reduced below $1000^{\circ} \mathrm{C}$ is iron. $[56,57]$

The area of the peaks is too small to account for the $\mathrm{Fe}(\mathrm{III}) \rightarrow \mathrm{Fe}(\mathrm{II})$ reduction; this means that the observed signals correspond only to the reduction of small amounts of $\mathrm{Fe}(\mathrm{IV})$ to $\mathrm{Fe}(\mathrm{III})$ and, successively, of $\mathrm{Fe}(\mathrm{III})$ to $\mathrm{Fe}(\mathrm{II})$. The presence of $\mathrm{Fe}^{4+}$ in this brownmillerite is not unexpected [58] and probably the $\mathrm{Mg}$ atoms inserted in the $\mathrm{Ca}_{2} \mathrm{FeAlO}_{5}$ structure are involved in its formation. 


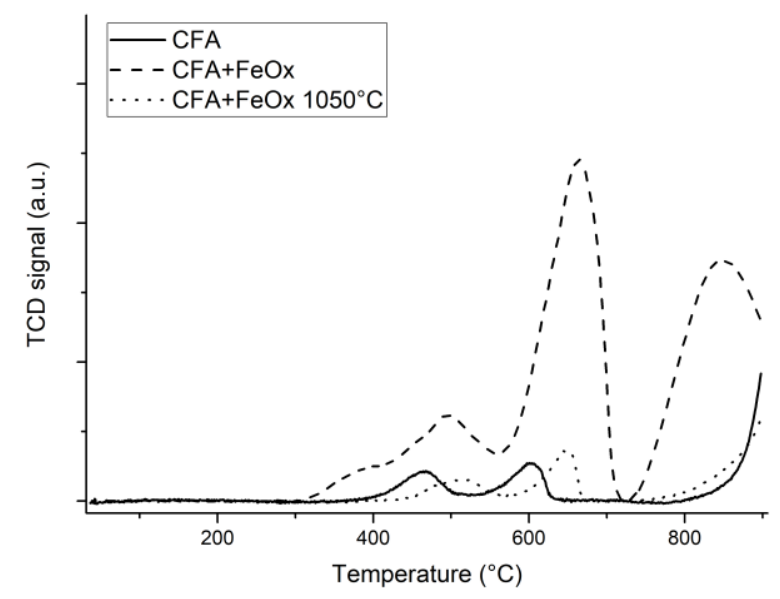

Figure 3 TPR profiles of synthesized powders.

\begin{tabular}{|l|l|l|}
\hline & $\mathbf{4 5 0}^{\circ} \mathbf{C}$ & $\mathbf{6 5 0}^{\circ} \mathbf{C}$ \\
\hline $\mathbf{C F A}$ & 0.010 & 0.012 \\
\hline $\mathbf{C F A}+\mathbf{F e O}_{\mathbf{x}}$ & $0.005+0.045$ & 0.172 \\
\hline $\mathbf{C F A}+\mathbf{F e O}_{\mathbf{x}} \mathbf{1 0 5 0}^{\circ} \mathbf{C}$ & 0.009 & 0.016 \\
\hline
\end{tabular}

Table 2. Hydrogen consumption in mol of $\mathrm{H}_{2} / \mathrm{mol}$ of $\mathrm{CFA}$ and $\mathrm{CFA}+\mathrm{FeO}_{\mathrm{x}}$ before and after the treatment at $1050^{\circ} \mathrm{C}$ necessary to reconstruct the brownmillerite structure.

The amount of $\mathrm{Fe}^{4+}$ ions, as determined by these measurements, roughly corresponds to the amount of magnesium, suggesting that iron atoms were oxidized to $4+$ to balance magnesium $2+$ charge, in accordance with literature.[36] TPR profiles of $\mathrm{Ca}_{2} \mathrm{FeAlO}_{5}$ report [59] only one small reduction peak at $700-800{ }^{\circ} \mathrm{C}$, so confirming this interpretation. Only the beginning of the curve corresponding to the reduction to $\mathrm{Fe}(0)$ is observed (above $800^{\circ} \mathrm{C}$ ). [56-57] The impregnation with iron heavily modifies the TPR profile in agreement with the phase transitions observed by XRD. $\mathrm{Ca}_{2} \mathrm{Fe}_{2} \mathrm{O}_{5}$ is the phase to be related with the TPR response as it is the only one containing iron; indeed, observed peaks are compatible with what described in literature about this phase [60]; the higher hydrogen consumption can be related also to the increased specific surface area. The two peaks between $400^{\circ} \mathrm{C}$ and $600^{\circ} \mathrm{C}$ are compatible with the presence of $\mathrm{Fe}_{2} \mathrm{O}_{3}$ that, according to 
literature [61], would be reduced with two non-resolved peaks having area ratio 1:8, as observed here. The signal at temperature lower than $400{ }^{\circ} \mathrm{C}$ is consistent with the reduction of Fe(IV). After the treatment at $1050^{\circ} \mathrm{C}$ a shape similar to pristine CFA is obtained again, due to the lower porosity of the material after sintering. The peak positions match very well with those of CFA-FeOx. This likely indicates that besides the regeneration of the CFA phase, after firing $\mathrm{Ca}_{2} \mathrm{Fe}_{2} \mathrm{O}_{5}$ is still present in the material. Due to the strong similarity between the two brownmillerite phases their presence in the XRD data is difficult to discern.

\subsection{Catalytic activity of the powders}

The catalytic activity of the electrodes used in SC-SOFCs is very important, as it has been mentioned in the introduction. For the efficiency's sake it is important to use, as starting point, materials with the lowest catalytic activity for methane oxidation. To obtain a result as close as possible to real cell operation, the same fuel/oxygen ratio used in SC-SOFCs has been used, the results are shown in Figure 4. The activity of CFA towards methane oxidation is low. Onset temperature is around $500^{\circ} \mathrm{C}$, then activity increases slowly with temperature, and at $600^{\circ} \mathrm{C}$ it is only modest (around $15 \%$ of oxygen conversion). The reaction reaches completion at $660^{\circ} \mathrm{C}$, the reactivity is considered low enough for making the material an adequate starting point. 


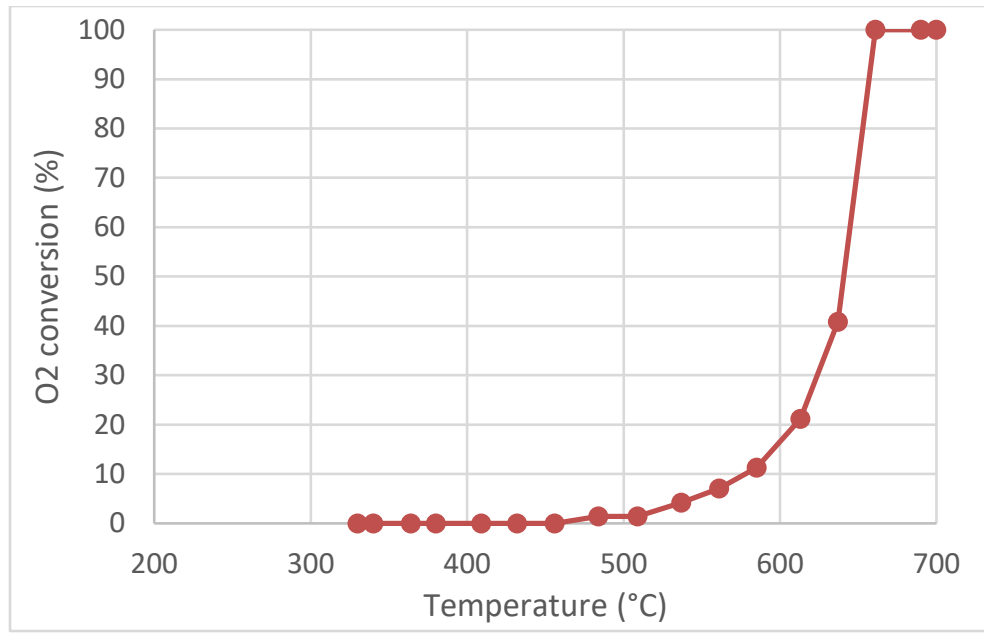

Figure 4. Oxygen conversion of CFA in fuel rich mixture $\left(\mathrm{CH}_{4} / \mathrm{O}_{2}=2\right)$. flow $100 \mathrm{sccm}, \mathrm{CH}_{4}=14 \%, \mathrm{O}_{2}=7 \%$.

\subsection{Electrochemical Impedance Spectroscopy and fuel cells performances}

The area specific resistance (ASR) determined as a function of temperature is summarized, for all the materials, in Figure 5. The electrochemical performance is not very different when comparing CFA treated at $1000^{\circ} \mathrm{C}$ and $1100^{\circ} \mathrm{C}$, and $\mathrm{CFA}+\mathrm{FeO}_{\mathrm{x}}$ treated at $1000^{\circ} \mathrm{C}$. A significant decrease is observed, in contrast, in $\mathrm{CFA}+\mathrm{FeO}_{\mathrm{x}}$ treated at $1100^{\circ} \mathrm{C}$ (i.e. when the brownmillerite structure is reconstructed). In all cases but $\mathrm{CFA} 1000^{\circ} \mathrm{C}$, the resistance increases in $\mathrm{CH}_{4}+\mathrm{O}_{2}$ atmosphere but then significantly decreases when it is switches to air again. The lower resistance is obtained in $\mathrm{CFA}+\mathrm{FeO}_{\mathrm{x}} 1100^{\circ} \mathrm{C}$ after treatment in $\mathrm{CH}_{4}+\mathrm{O}_{2}$. 

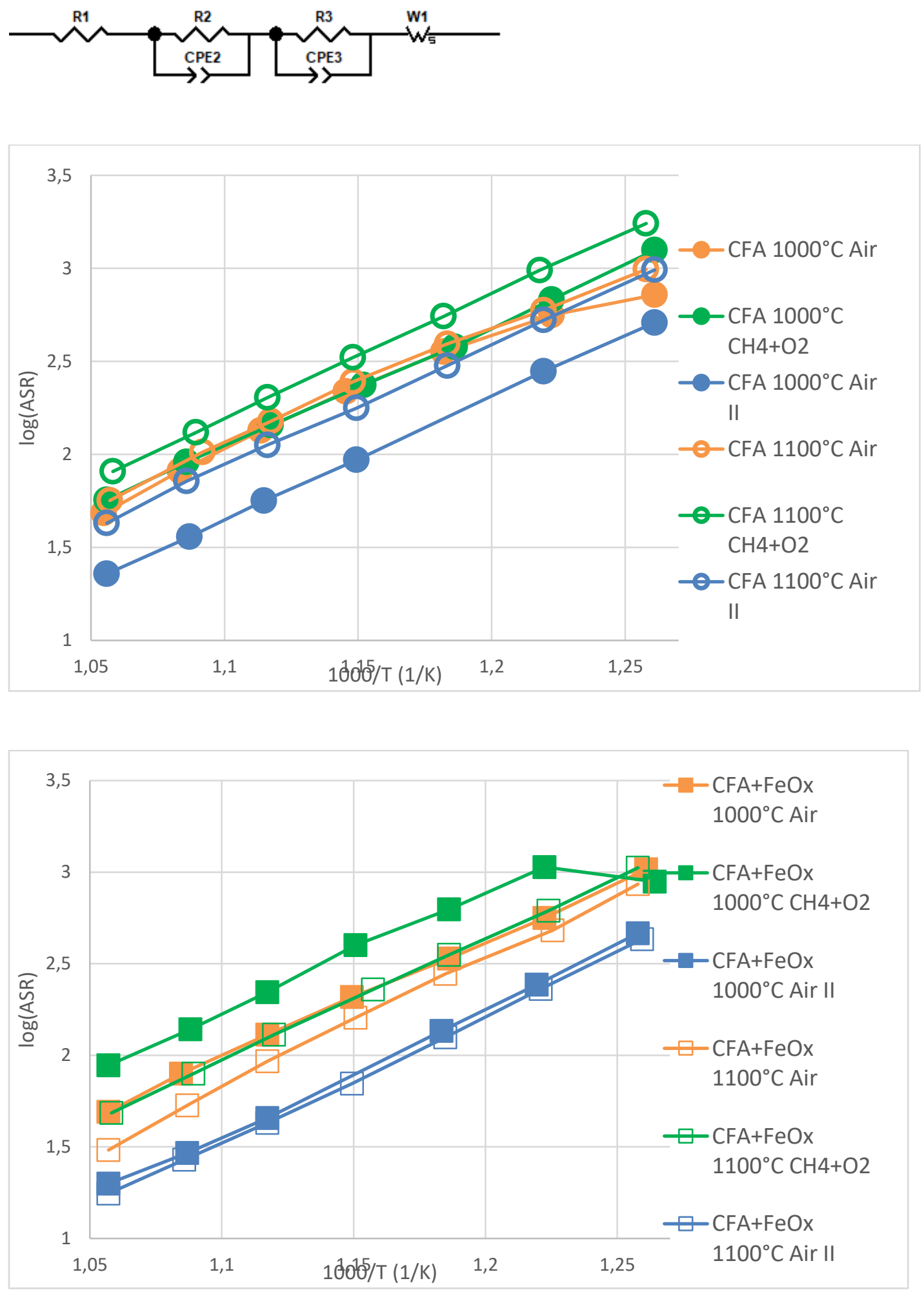

Figure 5. Above: model circuit used for EIS data fitting. Middle: ASR of CFA tested sample. Below: ASR of $\mathrm{CFA}+\mathrm{FeO}_{\mathrm{x}}$ tested samples. 

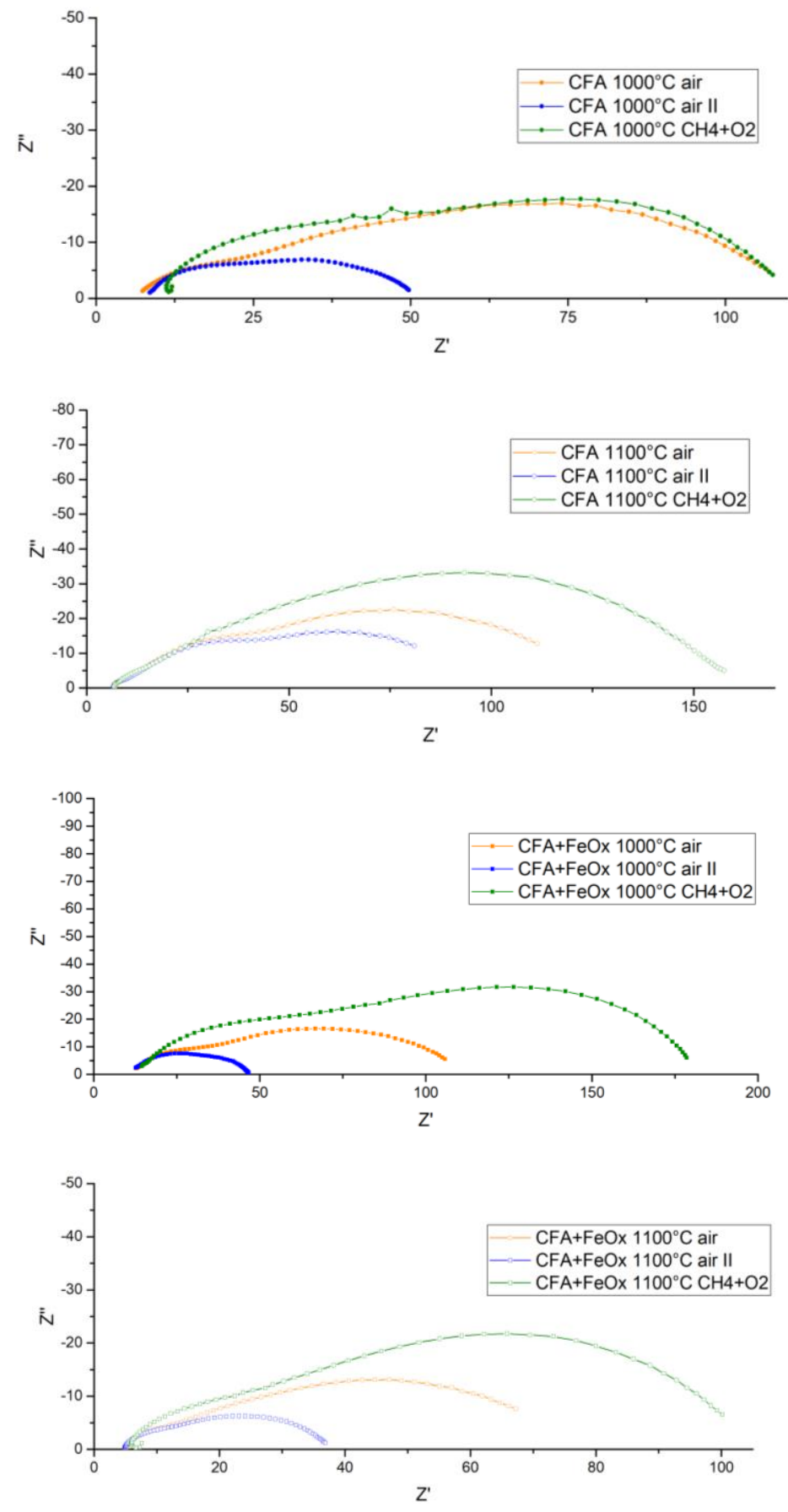

Figure 6. Nyquist plot of impedance spectra of symmetric cells at $620^{\circ} \mathrm{C}$. A: CFA tested at $1000^{\circ} \mathrm{C}$. B: $\mathrm{CFA}$ tested at $1100^{\circ} \mathrm{C}$. C: $\mathrm{CFA}+\mathrm{FeO}_{\mathrm{x}}$ tested at $1000^{\circ} \mathrm{C}$. CFA $+\mathrm{FeO}_{\mathrm{x}}$ tested at $1100^{\circ} \mathrm{C}$. Orange: first test under air. Blue: second test under air. Green: test under $\mathrm{CH}_{4}+\mathrm{O}_{2}$. 

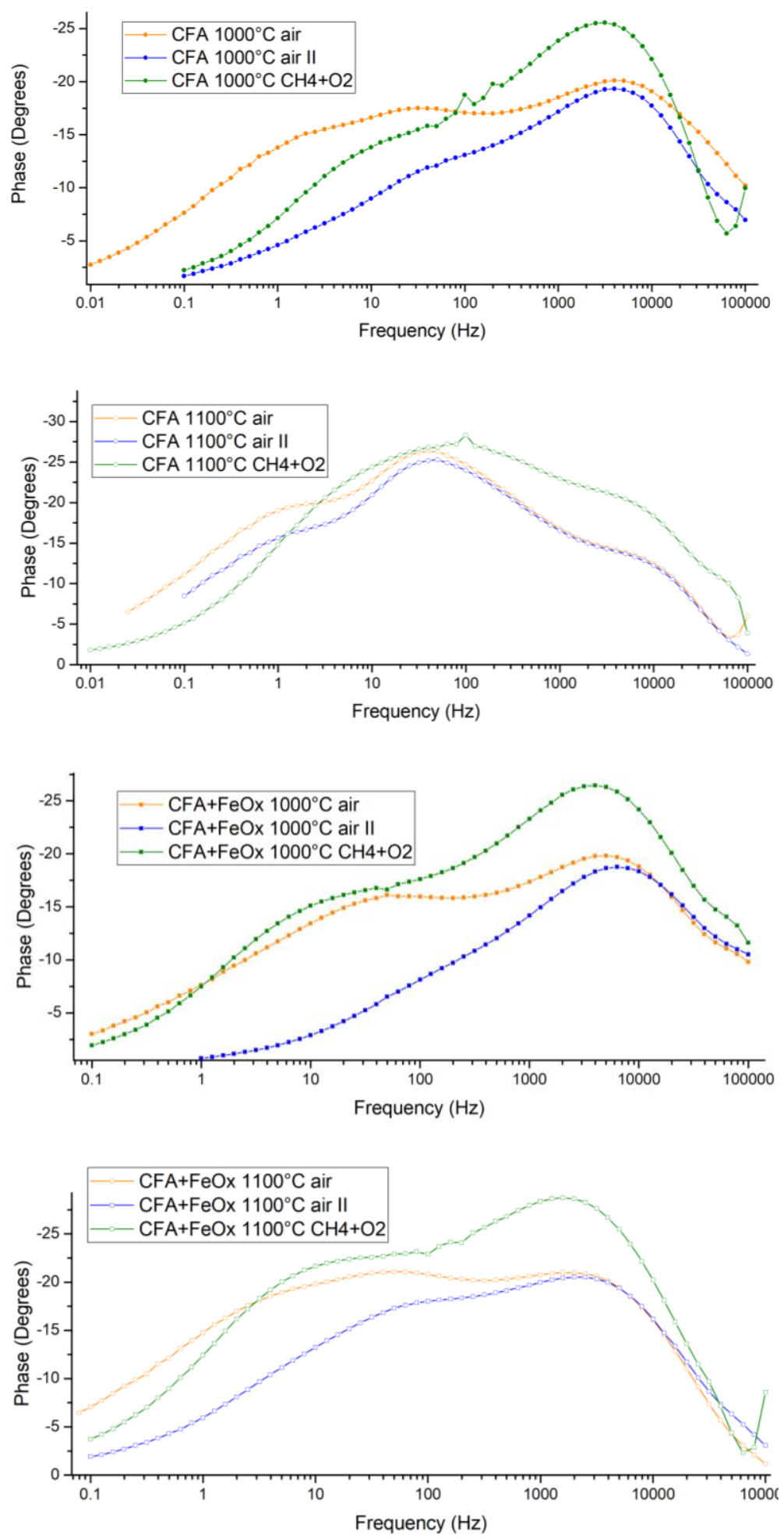

Figure 7. Bode plots of impedance phase of symmetric cells at $620^{\circ} \mathrm{C}$. A: CFA tested at $1000^{\circ} \mathrm{C}$. B: CFA tested at $1100^{\circ} \mathrm{C}$. C: $\mathrm{CFA}+\mathrm{FeO}_{\mathrm{x}}$ tested at $1000^{\circ} \mathrm{C}$. $\mathrm{CFA}+\mathrm{FeO}_{\mathrm{x}}$ tested at $1100^{\circ} \mathrm{C}$. Orange: first test under air. Blue: second test under air. Green: test under $\mathrm{CH}_{4}+\mathrm{O}_{2}$. 
The differences between the cathodes CFA and CFA $+\mathrm{FeO}_{\mathrm{x}}$ are small but significant. CFA is entirely composed by $\mathrm{Ca}_{2} \mathrm{FeAl}_{0.95} \mathrm{Mg}_{0.05} \mathrm{O}_{5}$ brownmillerite. $\mathrm{CFA}+\mathrm{FeO}_{\mathrm{x}}$ originally was $\mathrm{Ca}_{2} \mathrm{FeAl}_{0.95} \mathrm{Mg}_{0.05} \mathrm{O}_{5}$, then the $\mathrm{FeOx}$ induced the decomposition into at least 4 phases: srebrodolskite, mayenite, calcite (XRD). Finally, the thermal treatment during electrode firing, reversed phases to $\mathrm{Ca}_{2} \mathrm{FeAlO}_{5}$ and $\mathrm{Ca}_{2} \mathrm{Fe}_{2} \mathrm{O}_{5}$..

For the sake of clarity, only $620{ }^{\circ} \mathrm{C}$ EI spectra have been reported. Figure 6 shows the Nyquist plots, Figure 7 is the Bode plot of the phase, and Figure 8 shows the frequency shifts depending on temperature of the observed processes. It is possible to get some insight about mechanisms of the reaction. The way oxygen turns from molecular (in gas phase) to anion (in the electrolyte) depends heavily on cathode characteristics, including geometrical ones as porosity, tortuosity, thickness, and chemical ones (surface active sites, electron exchange, etc), ionic and electronic conductivity.

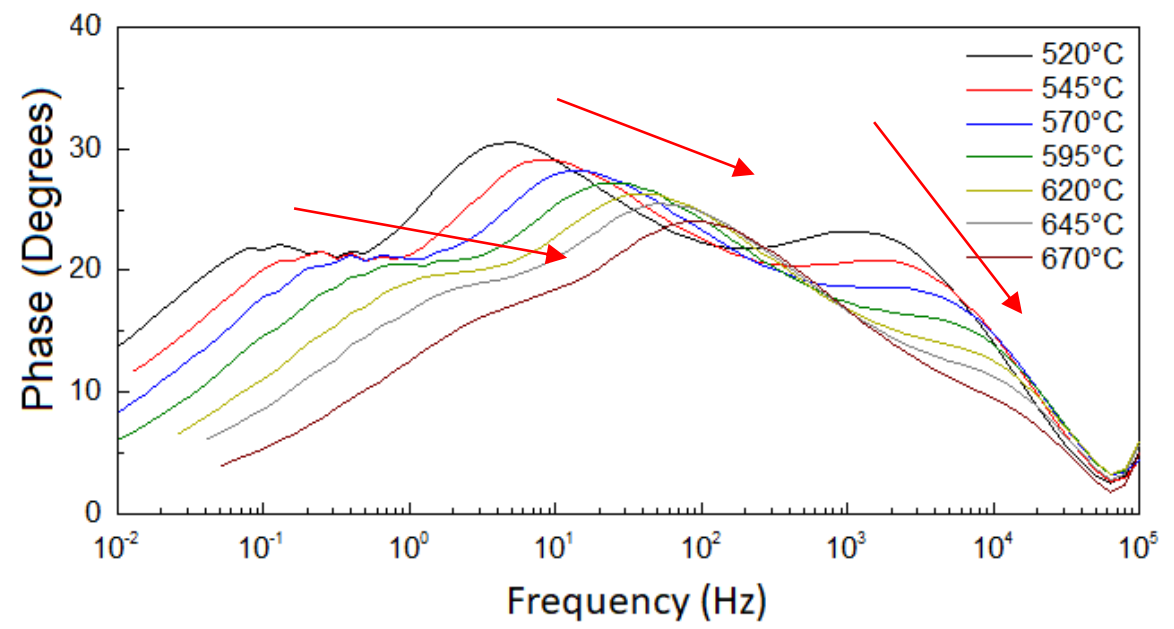

Figure 8. Bode plot of the impedance phase of CFA treated at $1100^{\circ} \mathrm{C}$ under air (first measurement), showing the frequency shifts of the resistive processes depending on temperature.

The different atmospheres the sample experiences in this series of tests, (air followed by $\mathrm{CH}_{4}+\mathrm{O}_{2}$ followed by air) can affect the ongoing process and modify the sample. When changing from air 
to oxygen/methane mixture, surface sites undergo reduction, and the amount of oxygen vacancies increases.[56-57] These effects sum, and when reverting to oxygen, equal results are never obtained. Instead, a second measurement (not reported for sake of clarity) under $\mathrm{CH}_{4}+\mathrm{O}_{2}$ always gives the same results of the first one.

Under air, up to three different resistive processes can be distinguished: on the basis of their frequency they can be labelled as High Frequency (HF), Medium Frequency (MF) and Low Frequency (LF); the latter is observed only in some samples and conditions.

The resistance of the HF process is highly dependent on oxygen concentration in all the samples, and its apex frequency is dependent on the temperature. It is fitted with a R//CPE element (Figure 5). The frequency close to $10^{4} \mathrm{~Hz}$ in SOFCs can be attributed to the $\mathrm{O}^{2-}$ transfer at the electrode/electrolyte interface [62], the observed capacitance around $10^{-5} \mathrm{Fcm}^{-2}$, compatible with a double layer, is consistent with this interpretation [63]. The $\mathrm{O}^{2-}$ transfer depends on the phases really composing the interface. These phases can differ from the bulk ones, and their formation can be influenced by the atmosphere (hence $\mathrm{pO}_{2}$ ) [64]. This phenomenon has already been observed in other cases, as for YSZ/LSM interfaces [65], and related to changes of the impedance response [66]. In this particular case, however, the different degree of aggregation and oxidation of iron oxide clusters, can deeply effect the electronic properties (Electron affinity, Fe-O and FeFe bond strength) and thus the electrochemical response [67].

The MF process depends on the atmosphere, its apex frequency is strongly influenced by the temperature and is well fitted be a R//CPE. It is the main contribution to resistance, and probably represents the oxygen reduction process; its resistance slightly increases from air to $\mathrm{CH}_{4}+\mathrm{O}_{2}$ and strongly decreases when going back to air. The reduction of some superficial sites, carried out by 
methane, can potentially modify catalytic activity permanently, and could be at the base of the changes of the resistance. Experimental and theoretical evaluation demonstrated, in fact, that in particular cases, the strain in the iron particles and the forces between the methane and the nearsurface iron and oxygen atoms can induce the dissociative chemisorption of methane [68].

The LF process is very well fitted by a Warburg element, the change of atmosphere from air to $\mathrm{CH}_{4}+\mathrm{O}_{2}$ make it disappear, and only in the samples treated at $1100^{\circ} \mathrm{C}$ it is observed again during the second measurement in air. $\mathrm{CFA}+\mathrm{FeO}_{\mathrm{x}}$ never features it. Diffusive processes at very low frequencies can be associated to oxygen diffusion inside the porosities of the electrode [69], but in this case the decrease of resistance when $\mathrm{pO}_{2}$ decreases excludes this interpretation (diffusion of oxygen is easier when it is more concentrated, not the opposite). So, this process could be related to the electrode diffusion of oxygen ions (either superficial or bulk, depending on preferred path). Focusing on bulk, a decrease of $\mathrm{pO}_{2}$ can induce an increase of vacancies of CFA and speeds up ionic conduction; on the other hand, diffusion of $\mathrm{O}^{2-}$ in bulk electrode is in general observed ad higher frequencies [70]. Considering surface, beside oxygen vacancies change, it has to be considered that active sites can be modified by atmosphere and the mobility of adsorbed oxygen can vary depending on $\mathrm{pO}_{2}$.

The reason why the LF process is observed only in some case is that this process is related to a specific path for the conduction of oxygen; consistently, its presence indicates that only under these conditions oxygen moves via the path the LF semicircle is associated with. The process is very temperature sensitive (Figure 8), and tends to shift at higher frequency and disappear at increasing temperature. This remarkable change suggests a change of the limiting phenomenon. Such a result would be in accordance with a surface diffusion. 
As observed, in general, overall resistance is higher when the atmosphere is changed to $\mathrm{CH}_{4}+\mathrm{O}_{2}$, because of a significant increase of the resistances associated to the HF and MF processes. So, it appears that the LF process is able in some way to ease the other two processes, in fact when it is present, the overall resistance is lower than the case in which the HF and MF processes are alone. After all, considering the performances observed with these measurements, the performance of CFA is mediocre, compared to other materials; its ASR is one order of magnitude higher than state of the art materials. Nonetheless, this material shows a remarkably low activation energy, close to $0.02 \mathrm{eV}$. This value is even lower than state-of-the-art LSCF [71], as can be seen in Table S3. This makes CFA an interesting candidate for high temperature cells.
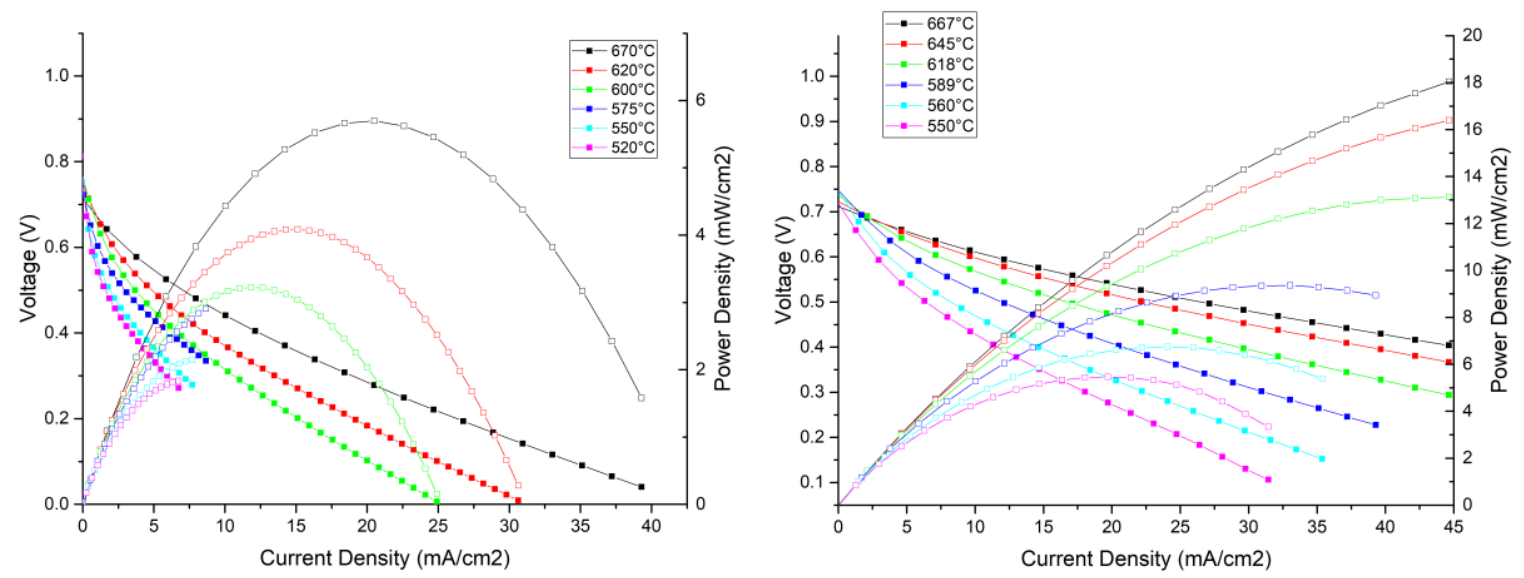

Figure 9. Polarization curves and power of cells with $\mathrm{CFA}$ treated at $1000^{\circ} \mathrm{C}$ (left) and $\mathrm{CFA}+\mathrm{FeO}$ (right) treated at $1100^{\circ} \mathrm{C}$ (right) cathodes. Anode is $\mathrm{Ni} / \mathrm{CGO}$ and electrolyte is CGO 
Figure 9 shows the current and power output of complete single chamber fuel cells with CFA based cathodes. Two cells have been tested, one with CFA and one with $\mathrm{CFA}+\mathrm{FeO}_{\mathrm{x}}$. Cathodes have been fired at the temperature that allowed to reach the lowest resistance during EIS measurements, so $1000^{\circ} \mathrm{C}$ for $\mathrm{CFA}$ and $1100^{\circ} \mathrm{C}$ for $\mathrm{CFA}+\mathrm{FeO}_{\mathrm{x}}$. The results of these measurements prove that CFA actually work as cathode for single chamber fuel cells. Compared to state-of-the-art cells, the power output is low, as it could be expected from the high ASR from single chamber measurements. In any case, it is remarkable that a material never tested for this application, without any kind of noble, toxic, rare or expensive component, is able to operate a fuel cell. ASR of CFA and CFA + $\mathrm{FeO}_{\mathrm{x}}$ as measured by EIS in symmetric cell, were almost similar, nonetheless power obtained from polarization curve are quite different. In fact, $\mathrm{CFA}+\mathrm{FeO}_{\mathrm{x}}$ is able to produce a power output three times higher than CFA, reaching values close to $20 \mathrm{mWcm}^{-}$ 2. We attribute this finding to the formation of the more conductive $\mathrm{Ca}_{2} \mathrm{Fe}_{2} \mathrm{O}_{5}$ phase, which is retained after firing, as showed by TEM. [72]

So, the phase transformation after impregnation with an iron solution, was effectively able to improve the performances of the material. Power output of a cell with CFA based cathode could be even better in double chamber architecture: as measured by means of EIS, the resistance in air is $1 / 3$ the one under the atmosphere single chamber cells operate, so better values would be probably obtained under atmospheres richer in oxygen.

As already mentioned, selectivity of the cathode is one of the most difficult and important issues in SC-SOFCs. In order to verify if the selectivity target has been reached, some preliminary test has been performed on the same cathodes tested in complete cells. Ideally, from the outlet of the cathode only oxygen, methane and inert gases should be found. All the product of a combustion (as $\mathrm{CO}_{2}$ and $\mathrm{CO}$ ) are result of parasitic undesired reactions. The results were found to be identical 
in both the tests of CFA and CFA $+\mathrm{FeO}_{x}$, this means that the processes involved in the parasitic reactions were only catalytic: if electrocatalysis was involved, it would have had some dependence on the cell power.

During the selectivity tests, a concentration of $400 \mathrm{ppm}$ of $\mathrm{CO}_{2}$ was detected, and no $\mathrm{CO}$ was found, with no difference depending on electrolyte (YSZ/CGO) or cathode (CFA or CFA $+\mathrm{FeO}_{\mathrm{x}}$ ). The absence of variations in the cells suggests that the traces of $\mathrm{CO}_{2}$ originate from non-catalysed direct oxidation. This is confirmed by the absence of difference between the CGO and YSZ-based cells, standing the relevant differences in catalytic activity. Considering methane Low Heating Value (LHV) as a reference and comparing with the gas flow, this methane conversion corresponds to a power loss of $30 \mathrm{~mW}$. This is a very promising result: if the power loss were the same also at the anode side, the cell would have been able to convert into energy $25 \%$ of the consumed fuel. The similarity of $\mathrm{CO}_{2}$ formation observed with $\mathrm{CGO}$ and YSZ-based cells, means methane loss due to catalytic activity is low, so there is significant room for selectivity improvement.

Then, an optimization of the electrode deposition would be appropriate, as well as a more accurate gas management. With those described improvements, a SC-SOFC based on CFA has strong chances of attaining the best efficiency ever for a SC-SOFC. On the other hand, as it was in the premises of this work, the power output would not compare with current double chamber SOFC, but this is evidently the price to pay for selectivity.

\section{Conclusions}

A specific material for cathodes of SC-SOFCs, $\mathrm{Ca}_{2} \mathrm{FeAl}_{0.95} \mathrm{Mg}_{0.05} \mathrm{O}_{5}$, has been designed aiming to obtain a material with specific properties in terms of process efficiency. During the material design, the requirement of a high final power output was deliberately dropped in order to maximize the 
results. $\mathrm{CFA}$ and its derivative $\mathrm{CFA}+\mathrm{FeO}_{\mathrm{x}}$ have been successfully synthesized and completely characterized. Symmetrical cells with CFA and CFA $+\mathrm{FeO}_{\mathrm{x}}$ have been fabricated and tested by means of EIS, the respective electrode firing temperatures have been optimized. ASR were calculated, obtaining high overall values, but in line with expectations. Then, complete cells have been prepared and tested as power output and, preliminary, efficiency. Results confirm initial targets were reached, as cell showed an optimal efficiency.

\section{ASSOCIATED CONTENT}

Supplementary Material. The following files are available free of charge. XRD patterns (PDF), $\mathrm{N}_{2}$ physisorption.

\section{ACKNOWLEDGMENT}

The authors want to express their gratitude to Dr. Clematis from University of Genova, for his great help in the interpretation of EIS spectra.

\section{REFERENCES}

[1] Hibino T, Iwahara H. Simplification of Solid Oxide Fuel Cell System Using Partial Oxidation of Methane. Chem Lett 1993;22:1131-4. https://doi.org/10.1246/cl.1993.1131.

[2] Brett DJL, Atkinson A, Brandon NP, Skinner SJ. Intermediate temperature solid oxide fuel cells. Chem Soc Rev 2008;37:1568. https://doi.org/10.1039/b612060c.

[3] Yano M, Tomita A, Sano M, Hibino T. Recent advances in single-chamber solid oxide fuel cells : A review 2007;177:3351-9. https://doi.org/10.1016/j.ssi.2006.10.014. 
[4] Kuhn M, Napporn TW. Single-Chamber Solid Oxide Fuel Cell Technology—From Its Origins to Today's State of the Art. Energies 2010;3:57-134. https://doi.org/10.3390/en3010057.

[5] Briault P, Rieu M, Laucournet R, Morel B, Viricelle J-P. Anode supported single chamber solid oxide fuel cells operating in exhaust gases of thermal engine. J Power Sources 2014;268:356-64. https://doi.org/10.1016/j.jpowsour.2014.06.061.

[6] Riess I. On the single chamber solid oxide fuel cells. J Power Sources 2008;175:325-37. https://doi.org/10.1016/j.jpowsour.2007.09.041.

[7] Shao Z, Haile SM, Ahn J, Ronney PD, Zhan Z, Barnett S a. A thermally self-sustained micro solid-oxide fuel-cell stack with high power density. Nature 2005;435:795-8. https://doi.org/10.1038/nature03673.

[8] Kuhn M, Napporn TW, Meunier M, Vengallatore S, Therriault D. Miniaturization limits for single-chamber micro-solid oxide fuel cells with coplanar electrodes. J Power Sources 2009;194:941-9. https://doi.org/10.1016/j.jpowsour.2009.05.034.

[9] Kuhn M, Napporn TW, Meunier M, Therriault D. Single-chamber micro solid oxide fuel cells : Study of anode and cathode materials in coplanar electrode design. Solid State Ionics 2010;181:332-7. https://doi.org/10.1016/j.ssi.2010.01.012.

[10] Riess I. Catalytic Requirements for Mixed Reactant Fuel Cells. Funct Mater Lett 2008;01:105-13. https://doi.org/10.1142/S1793604708000198.

[11] Riess I. Significance of impeded reactions in solid state electrochemistry-Conspicuous 
examples. Solid State Ionics 2006;177:1591-6. https://doi.org/10.1016/j.ssi.2005.11.016.

[12] Riess I. The significance of impeded reactions in solid state electrochemistry. Solid State Ion BT - 7th Int Symp Syst with Fast Ion Transp 2004;176:1667-74. https://doi.org/10.1016/j.ssi.2005.04.015.

[13] Riess I. Catalysis of electrochemical processes and the suppression of chemical ones are needed in mixed reactant fuel cells - Can this be achieved? Solid State Ionics 2010;181:790-5. https://doi.org/10.1016/j.ssi.2010.04.033.

[14] Rembelski D, Rieu M, Combemale L, Viricelle JP. In situ reduction and evaluation of anode supported single chamber solid oxide fuel cells. J Power Sources 2013;242:811-6. https://doi.org/10.1016/j.jpowsour.2013.05.118.

[15] Morel B, Roberge R, Savoie S, Napporn TW, Meunier M. Temperature and performance variations along single chamber solid oxide fuel cells. J Power Sources 2009;186:89-95. https://doi.org/10.1016/j.jpowsour.2008.09.087.

[16] Yang G, Su C, Wang W, Ran R, Tadé MO, Shao Z. Single-chamber solid oxide fuel cells with nanocatalyst-modified anodes capable of in situ activation. J Power Sources 2014;264:220-8. https://doi.org/10.1016/j.jpowsour.2014.04.091.

[17] Faes A, Hessler-Wyser A, Zryd A, Van Herle J. A review of RedOx cycling of solid oxide fuel cells anode. Membranes (Basel) 2012;2:585-664. https://doi.org/10.3390/membranes2030585.

[18] Wang ZH, Lü Z, Chen KF, Wei B, Zhu XB, Huang XQ, et al. Redox Tolerance of Thin and 
Thick Ni/YSZ Anodes of Electrolyte-Supported Single-Chamber Solid Oxide Fuel Cells under Methane Oxidation Conditions. Fuel Cells 2013;13:1109-15. https://doi.org/10.1002/fuce.201200050.

[19] Gadacz G, Viricelle J-P, Pijolat C, Pijolat M. Voltage Oscillations in Single-Chamber Fuel Cells Operating under a C 3 H 8 /O 2 Mixture. Fuel Cells 2013;13:1032-9. https://doi.org/10.1002/fuce.201300165.

[20] Viricelle J-P, Udroiu S, Gadacz G, Pijolat M, Pijolat C. Development of Single Chamber Solid Oxide Fuel Cells (SCFC). Fuel Cells 2010;10:683-92. https://doi.org/10.1002/fuce.200900146.

[21] Rembelski D, Viricelle JP, Combemale L, Rieu M. Characterization and Comparison of Different Cathode Materials for SC-SOFC: LSM, BSCF, SSC, and LSCF. Fuel Cells 2012;12:256-64. https://doi.org/10.1002/fuce.201100064.

[22] Yin J-W, Zhang C, Yin Y-M, Shi H, Lin Y, Lu J, et al. Anode-supported single-chamber solid oxide fuel cell based on cobalt-free composite cathode of $\mathrm{Nd} 0.5 \mathrm{Sr} 0.5 \mathrm{Fe} 0.8 \mathrm{Cu} 0.2 \mathrm{O} 3-\delta-\mathrm{Sm} 0.2 \mathrm{Ce} 0.8 \mathrm{O} 1.9$ at intermediate temperatures. $\mathrm{J}$ Power Sources 2015;286:217-23. https://doi.org/10.1016/j.jpowsour.2015.03.173.

[23] Sun LP, Rieu M, Viricelle JP, Pijolat C, Zhao H. Fabrication and characterization of anodesupported single chamber solid oxide fuel cell based on $\mathrm{La} 0.6 \mathrm{Sr} 0.4 \mathrm{Co} 0.2 \mathrm{Fe} 0.8 \mathrm{O} 3-\delta-$ Ce0.9Gd0.101.95 composite cathode. Int J Hydrogen Energy 2014;39:1014-22. https://doi.org/10.1016/j.ijhydene.2013.10.117. 
[24] Gaudillère C, Olivier L, Vernoux P, Zhang C, Shao Z, Farrusseng D. Alternative perovskite materials as a cathode component for intermediate temperature single-chamber solid oxide fuel cell. J $\quad$ Power $\quad$ Sources 2010;195:4758-64. https://doi.org/10.1016/j.jpowsour.2010.02.058.

[25] Morales M, Piñol S, Segarra M. Intermediate temperature single-chamber methane fed SOFC based on Gd doped ceria electrolyte and $\mathrm{La} 0.5 \mathrm{Sr} 0.5 \mathrm{CoO} 3-\delta$ as cathode. J Power Sources 2009;194:961-6. https://doi.org/10.1016/j.jpowsour.2009.05.027.

[26] Zhang C, Zheng Y, Lin Y, Ran R, Shao Z, Farrusseng D. A comparative study of $\mathrm{La} 0.8 \mathrm{Sr} 0.2 \mathrm{MnO} 3$ and $\mathrm{La} 0.8 \mathrm{Sr} 0.2 \mathrm{Sc} 0.1 \mathrm{Mn} 0.9 \mathrm{O} 3$ as cathode materials of single-chamber SOFCs operating on a methane-air mixture. J Power Sources 2009;191:225-32. https://doi.org/10.1016/j.jpowsour.2009.02.043.

[27] Zhang C, Zheng Y, Ran R, Shao Z, Jin W, Xu N, et al. Initialization of a methane-fueled single-chamber solid-oxide fuel cell with $\mathrm{NiO}+\mathrm{SDC}$ anode and $\mathrm{BSCF}+\mathrm{SDC}$ cathode. $\mathrm{J}$ Power Sources 2008;179:640-8. https://doi.org/10.1016/j.jpowsour.2008.01.030.

[28] Wei B, Lü Z, Huang X, Liu M, Chen K, Su W. Enhanced performance of a single-chamber solid oxide fuel cell with an SDC-impregnated cathode. J Power Sources 2007;167:58-63. https://doi.org/10.1016/j.jpowsour.2007.02.017.

[29] Sun C, Hui R, Roller J. Cathode materials for solid oxide fuel cells: a review. J Solid State Electrochem 2010;14:1125-44. https://doi.org/10.1007/s10008-009-0932-0.

[30] Gong, Y., Sun, C., Huang Q., Alonso J.A., Fernandez-Díaz M.T., Chen L.; Dynamic 
Octahedral Breathing in Oxygen-Deficient $\mathrm{Ba}_{0.9} \mathrm{Co}_{0.7} \mathrm{Fe}_{0.2} \mathrm{Nb}_{0.1} \mathrm{O}_{3-\delta}$ Perovskite Performing as a Cathode in Intermediate-Temperature SOFC Inorg. Chem. 2016;55:3091-3097 https://doi.org 10.1021/acs.inorgchem.5b03002

[31] Sun C., Alonso J.A., Bian J. Recent Advances in Perovskite-Type Oxides for Energy Conversion and Storage Applications Adv. Energy Mater. 2020, 2000459 https://doi.org 10.1002/aenm.202000459

[32] Yang W., Zhang H., Sun C., Liu L., Alonso J.A., Fernandez-Díaz M. T., Chen L. Insight into the Structure and Functional Application of the $\mathrm{Sr}_{0.95} \mathrm{Ce}_{0.05} \mathrm{CoO}_{3-\delta}$ Cathode for Solid Oxide Fuel Cells Inorg. Chem. 2015;54:3477-3484 https://doi.org 10.1021/acs.inorgchem.5b00051

[33] Yang W., Hong T., Li S., Ma Z., Sun C., Xia C., Chen L. Perovskite $\mathrm{Sr}_{1-x} \mathrm{Ce}_{x} \mathrm{CoO}_{3-\delta}(0.05 \leq$ $\mathrm{x} \leq 0.15)$ as Superior Cathodes for Intermediate Temperature Solid Oxide Fuel Cells ACS Appl. Mater. Interfaces 2013;5:1143-8 dx.doi.org/10.1021/am3029238

[34] Geffroy P-M, Fouletier J, Richet N, Chartier T. Rational selection of MIEC materials in energy production processes. Chem Eng Sci 2013;87:408-33. https://doi.org/10.1016/j.ces.2012.10.027.

[35] Tao Y, Zhang W, Li N, Wang F, Hu S. Atomic occupancy mechanism in brownmillerite Ca 2 FeAlO 5 from a thermodynamic perspective. J Am Ceram Soc 2020;103:635-44. https://doi.org/10.1111/jace.16711.

[36] Malveiro J, Ramos T, Ferreira LP, Waerenborgh JC, Nunes MR, Godinho M, et al. 
Magnesium doping on brownmillerite $\mathrm{Ca}_{2} \mathrm{FeAlO}_{5}$. J Solid State Chem 2007;180:1863-74. https://doi.org/10.1016/j.jssc.2007.04.009.

[37] Thundiyil S, Kurungot S, Devi RN. Bifunctional Oxygen Reduction and Evolution Activity in Brownmillerites $\mathrm{Ca}_{2} \mathrm{Fe}_{(1-\mathrm{x})} \mathrm{Co}_{\mathbf{x}} \mathrm{O}_{5} . \quad$ ACS Omega 2019;4:31-8. https://doi.org/10.1021/acsomega.8b02468.

[38] Li Q, Sun L, Huo L, Zhao H, Grenier J-C. Electrode properties of Co-doped $\mathrm{Ca}_{2} \mathrm{Fe}_{2} \mathrm{O}_{5}$ as new cathode materials for intermediate-temperature SOFCs. Int J Hydrogen Energy 2010;35:9151-7. https://doi.org/10.1016/j.ijhydene.2010.06.048.

[39] Cascos V, Martínez-Coronado R, Alonso JA, Fernández-Díaz MT. Structural and electrical characterization of the Co-doped $\mathrm{Ca}_{2} \mathrm{Fe}_{2} \mathrm{O}_{5}$ brownmillerite: Evaluation as $\mathrm{SOFC}$-cathode materials. Int J Hydrogen Energy 2015;40:5456-68. https://doi.org/10.1016/j.ijhydene.2015.01.067.

[40] Bligaard T, Nørskov JK. Heterogeneous Catalysis in Chemical Bonding at Surfaces and Interfaces. 2008.

[41] Cox PA. Transition Metal Oxides: An Introduction to Their Electronic Structure and Properties. Oxford, UK: Clarendond Press; 1992.

[42] Miyano T, Sakisaka Y, Komeda T, Onchi M. Electron energy-loss spectroscopy study of oxygen chemisorption and initial oxidation of Fe(110). Surf Sci 1986;169:197-215. https://doi.org/10.1016/0039-6028(86)90746-6.

[43] Sakisaka Y, Miyano T, Onchi M. Electron-energy-loss-spectroscopy study of oxygen 
chemisorption and initial oxidation of $\mathrm{Fe}(100)$. Phys Rev B 1984;30:6849-55. https://doi.org/10.1103/PhysRevB.30.6849.

[44] Carollo G, Garbujo A, Ferri D, Natile MM, Glisenti A. No Title. Hydrog. Fuel Cells, University of Maribor Press; n.d., p. 53-64. https://doi.org/10.18690/978-961-286-054-7.

[45] Perin G, Fabro J, Guiotto M, Xin Q, Natile MM, Cool P, et al. Cu@ $2 \mathrm{LaNiO}_{3}$ based nanocomposites in TWC applications. Appl Catal B Environ 2017;209:214-27. https://doi.org/10.1016/j.apcatb.2017.02.064.

[46] Bedon A, Rieu M, Viricelle J-P, Glisenti A. Rational Development of IT-SOFC Electrodes Based on the Nanofunctionalization of La $0.6 \mathrm{Sr} 0.4 \mathrm{Ga} 0.3 \mathrm{Fe} 0.7 \mathrm{O} 3$ with Oxides. PART 1: Cathodes by Means of Iron Oxide. ACS Appl Energy Mater 2018;1:6840-50. https://doi.org/10.1021/acsaem.8b01124.

[47] Ortiz-Vitoriano N, Ruiz de Larramendi I, Gil de Muro I, Larrañaga A, Ruiz de Larramendi JI, Rojo T. A novel one step synthesized Co-free perovskite/brownmillerite nanocomposite for solid oxide fuel cells. J Mater Chem 2011;21:9682. https://doi.org/10.1039/c1jm10911a.

[48] Lo Faro M, Reis RM, Saglietti GGA, Oliveira VL, Zignani SC, Trocino S, et al. Solid oxide fuel cells fed with dry ethanol: The effect of a perovskite protective anodic layer containing dispersed Ni-alloy@ FeOx core-shell nanoparticles. Appl Catal B Environ 2018;220:98110. https://doi.org/10.1016/j.apcatb.2017.08.010.

[49] Schwarz JA, Contescu C, Contescu A. Methods for Preparation of Catalytic Materials. Chem Rev 1995;95:477-510. https://doi.org/10.1021/cr00035a002. 
[50] Kung HH. Transition Metal Oxides Surface Chemistry and Catalysis. Elsevier B.V.; 1989.

[51] Shirley DA. High-resolution x-ray photoemission spectrum of the valence bands of gold. Phys Rev B 1972;5:4709-14. https://doi.org/10.1103/PhysRevB.5.4709.

[52] Briggs D. Handbook of X-ray Photoelectron Spectroscopy C. D. Wanger, W. M. Riggs, L. E. Davis, J. F. Moulder and G. E.Muilenberg Perkin-Elmer Corp., Physical Electronics Division, Eden Prairie, Minnesota, USA, 1979. 190-195. Surf Interface Anal 1981;3. https://doi.org/10.1002/sia.740030412.

[53] McIntyre NS, in D. Briggs and M. P. Seah (eds.). Practical Surface Analysis in Auger and X-ray Photoelectron Spectroscopy. John Wiley Sons, New York 1983;1:397-427. https://doi.org/10.1016/S0039-9140(97)80038-0.

[54] Johnsson M, Lemmens P. Crystallography and Chemistry of Perovskites. Handb. Magn. Adv. Magn. Mater., Chichester, UK: John Wiley \& Sons, Ltd; 2007, p. 11. https://doi.org/10.1002/9780470022184.hmm411.

[55] Shaula A, Pivak Y, Waerenborgh J, Gaczynski P, Yaremchenko A, Kharton V. Ionic conductivity of brownmillerite-type calcium ferrite under oxidizing conditions. Solid State Ionics 2006;177:2923-30. https://doi.org/10.1016/j.ssi.2006.08.030.

[56] B. KayaalpLee S., Klauke K., Seo J., Nodari' L., Jung, Mascotto S.,Template-free mesoporous $\mathrm{La}_{0.3} \mathrm{Sr}_{0.7} \mathrm{Ti}_{1-\mathrm{x}} \mathrm{Fe}_{\mathrm{x}} \mathrm{O}_{3 \pm \delta}$ for $\mathrm{CH}_{4}$ and $\mathrm{CO}$ oxidation catalysis, Appl. Catal. B: Environ. 2019;245:536-545 https://doi.org/10.1016/j.apcatb.2018.12.077 
[57] Kayaalp B., Lee S., Nodari L., Seo J., Kim S., Jung W.C., Mascotto S. Pt Nanoparticles Supported on a Mesoporous $(\mathrm{La}, \mathrm{Sr})(\mathrm{Ti}, \mathrm{Fe}) \mathrm{O}_{3-\delta}$ Solid Solution for the Catalytic Oxidation of $\mathrm{CO}$ and $\mathrm{CH}_{4}$ ACS Appl. Nano Mater. 2020;3,11:11352-11362 https://doi.org/10.1021/acsanm.0c02456

[58] Waerenborgh JC, Rojas DP, Vyshatko NP, Shaula AL, Kharton VV, Marozau IP, et al. Fe4+ formation in brownmillerite $\mathrm{CaAl}_{0.5} \mathrm{Fe}_{0.5} \mathrm{O}_{2.5+\delta}$. Mater Lett 2003;57:4388-93. https://doi.org/10.1016/S0167-577X(03)00330-6.

[59] Tian S, Jiang J, Hosseini D, Kierzkowska AM, Imtiaz Q, Broda M, et al. Development of a Steel-Slag-Based, Iron-Functionalized Sorbent for an Autothermal Carbon Dioxide Capture Process - Supporting Information. ChemSusChem 2015;8:3839-46. https://doi.org/10.1002/cssc.201501048.

[60] Hirabayashi D, Yoshikawa T, Mochizuki K, Suzuki K, Sakai Y. Formation of brownmillerite type calcium ferrite $\left(\mathrm{Ca}_{2} \mathrm{Fe}_{2} \mathrm{O}_{5}\right)$ and catalytic properties in propylene combustion. Catal Letters 2006;110:269-74. https://doi.org/10.1007/s10562-006-0120-0.

[61] Liang M, Kang W, Xie K. Comparison of reduction behavior of $\mathrm{Fe}_{2} \mathrm{O}_{3}, \mathrm{ZnO}$ and $\mathrm{ZnFe}_{2} \mathrm{O}_{4}$ by TPR technique. J Nat Gas Chem 2009;18:110-3. https://doi.org/10.1016/S10039953(08)60073-0.

[62] Ringuedé A, Fouletier J. Oxygen reaction on strontium-doped lanthanum cobaltite dense electrodes at intermediate temperatures. Solid State Ionics 2001;139:167-77. https://doi.org/10.1016/S0167-2738(01)00692-0.

[63] Yang YL, Jacobson AJ, Chen CL, Luo GP, Ross KD, Chu CW. Oxygen exchange kinetics 
on a highly oriented La0.5 $\mathrm{Sr} 0.5 \mathrm{CoO} 3-$ ?? thin film prepared by pulsed-laser deposition. Appl Phys Lett 2001;79:776-8. https://doi.org/10.1063/1.1390316.

[64] Adler SB. Factors governing oxygen reduction in solid oxide fuel cell cathodes. Chem Rev Rev 2004;104:4791-843. https://doi.org/10.1021/Cr020724o.

[65] Kawada T, Sakai N, Yokokawa H, Dokiya M, Anzai I. Reaction Between Solid Oxide FuelCell Materials. Solid State Ionics 1992;50:189-96. https://doi.org/10.1016/01672738(92)90218-E.

[66] Liu M. Significance of interfaces in solid-state cells with porous electrodes of mixed ionicelectronic conductors. Solid State Ionics 1998;107:105-10. https://doi.org/10.1016/S01672738(97)00528-6.

[67] Wang L-S, Wu H, Desai SR. Sequential Oxygen Atom Chemisorption on Surfaces of Small Iron Clusters. Phys Rev Lett 1996;76:4853-6. https://doi.org/10.1103/PhysRevLett.76.4853.

[68] Motozuka S, Tagaya M, Morinaga M, Ikoma T, Yoshioka T, Tanaka J. Methane adsorption and dissociation on mechanochemically activated iron-particle surfaces. Int $\mathrm{J}$ Powder Metall 2012;48:21-9.

[69] Flura A, Nicollet C, Fourcade S, Vibhu V, Rougier A, Bassat J-M, et al. Identification and modelling of the oxygen gas diffusion impedance in SOFC porous electrodes: application to $\quad \operatorname{Pr}_{2} \mathrm{NiO}_{4+\delta}$. Electrochim Acta 2015;174:1030-40. https://doi.org/10.1016/j.electacta.2015.06.084. 
[70] Grunbaum N, Dessemond L, Fouletier J, Prado F, Mogni L, Caneiro A. Rate limiting steps of the porous $\mathrm{La}_{0.6} \mathrm{Sr}_{0.4} \mathrm{Co}_{0.8} \mathrm{Fe}_{0.2} \mathrm{O}_{3-\delta}$ electrode material. Solid State Ionics 2009;180:144852. https://doi.org/10.1016/j.ssi.2009.09.005.

[71] Tai L. Structure and electrical properties of $\mathrm{La}_{1-x} \mathrm{Sr}_{x} \mathrm{Co}_{1-y} \mathrm{Fe}_{y} \mathrm{O}_{3}$. Part 1. The system $\mathrm{La}_{0.8} \mathrm{Sr}_{0.2} \mathrm{Co}_{1-\mathrm{y}} \mathrm{Fe}_{\mathrm{y}} \mathrm{O}_{3}$. Solid State Ionics 1995;76:259-71. https://doi.org/10.1016/01672738(94)00244-M.

[72] Shukl, A., Gaur, N.K. et al First principles investigations of structure, stability and electronic properties of polar $\mathrm{Ca}_{2} \mathrm{Fe}_{2} \mathrm{O}_{5}$ (010) surfaces; Appl. Surf. Sci. 2020:527:146703 

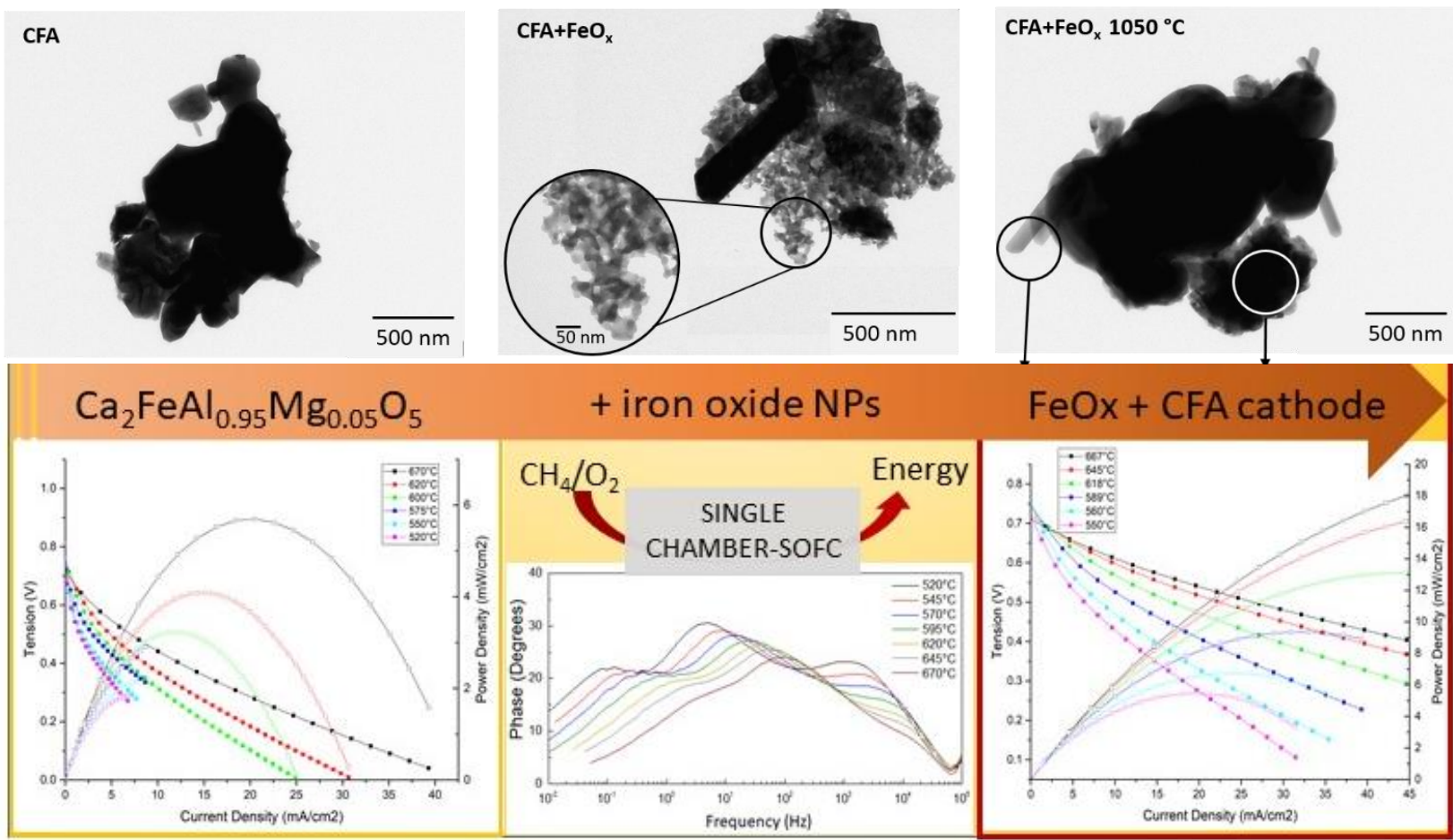

\section{+ iron oxide NPs}

FeOx + CFA cathode
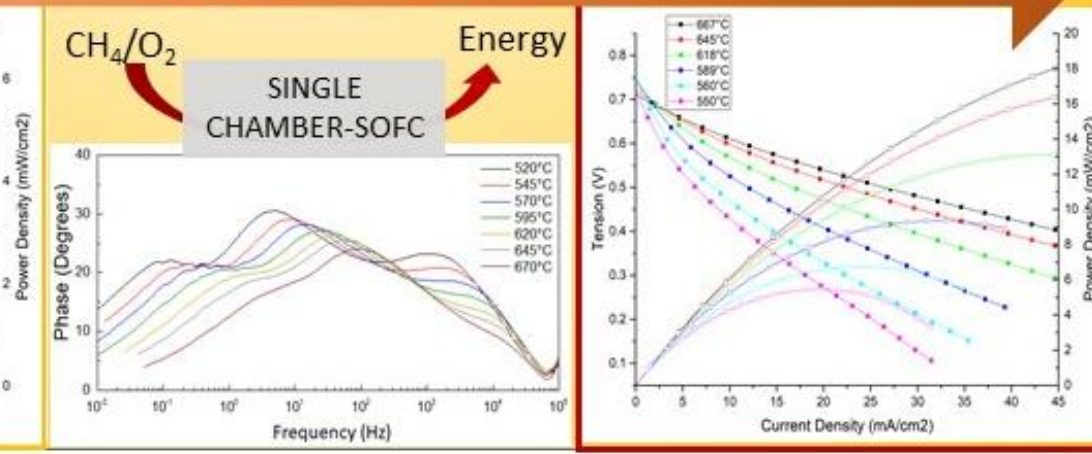